\title{
Genetic Modulation of Soluble A $\beta$ Rescues Cognitive and Synaptic Impairment in a Mouse Model of Alzheimer's Disease
}

\author{
Stephanie W. Fowler, ${ }^{1 \star}$ Angie C. A. Chiang, ${ }^{1 *}$ Ricky R. Savjani, ${ }^{1,3}$ Megan E. Larson, ${ }^{4}$ Mathew A. Sherman, ${ }^{4}$ \\ Dorothy R. Schuler, ${ }^{5}$ John R. Cirrito, ${ }^{5}$ Sylvain E. Lesné, ${ }^{4}$ and Joanna L. Jankowsky ${ }^{1,2}$ \\ ${ }^{1}$ Departments of Neuroscience and ${ }^{2}$ Neurology and Neurosurgery, Huffington Center on Aging, Baylor College of Medicine, Houston, Texas 77030, ${ }^{3}$ Texas \\ A\&M Health Science Center, College Station, Texas 77843, ${ }^{4}$ Department of Neuroscience, N. Bud Grossman Center for Memory Research and Care, and \\ Institute for Translational Neuroscience, University of Minnesota, Minneapolis, Minnesota 55454, and ${ }^{5}$ Department of Neurology, Washington University \\ School of Medicine, St. Louis, Missouri 63110
}

An unresolved debate in Alzheimer's disease $(\mathrm{AD})$ is whether amyloid plaques are pathogenic, causing overt physical disruption of neural circuits, or protective, sequestering soluble forms of amyloid- $\beta(\mathrm{A} \beta)$ that initiate synaptic damage and cognitive decline. Few animal models of AD have been capable of isolating the relative contribution made by soluble and insoluble forms of $\mathrm{A} \beta$ to the behavioral symptoms and biochemical consequences of the disease. Here we use a controllable transgenic mouse model expressing a mutant form of amyloid precursor protein (APP) to distinguish the impact of soluble $\mathrm{A} \beta$ from that of deposited amyloid on cognitive function and synaptic structure. Rapid inhibition of transgenic APP modulated the production of A $\beta$ without affecting pre-existing amyloid deposits and restored cognitive performance to the level of healthy controls in Morris water maze, radial arm water maze, and fear conditioning. Selective reduction of $A \beta$ with a $\gamma$-secretase inhibitor provided similar improvement, suggesting that transgene suppression restored cognition, at least in part by lowering $\mathrm{A} \beta$. Cognitive improvement coincided with reduced levels of synaptotoxic $\mathrm{A} \beta$ oligomers, greater synaptic density surrounding amyloid plaques, and increased expression of presynaptic and postsynaptic markers. Together these findings indicate that transient $\mathrm{A} \beta$ species underlie much of the cognitive and synaptic deficits observed in this model and demonstrate that significant functional and structural recovery can be attained without removing deposited amyloid.

Key words: amyloid; amyloid precursor protein; APP; oligomer; tetracycline transactivator; TTA

\section{Introduction}

Amyloid- $\beta(\mathrm{A} \beta)$ peptides produced by the cleavage of the amyloid precursor protein (APP) are a major focus of drug development for Alzheimer's disease (AD). However, there is little consensus about what form of $\mathrm{A} \beta$-monomer, small soluble assemblies, or aggregated deposits-should be targeted therapeutically. Initial testing in animal models suggested that cognitive protection could be achieved by lowering all forms of $\mathrm{A} \beta$ by

\footnotetext{
Received Feb. 8, 2014; revised April 4, 2014; accepted April 29, 2014.

Author contributions: S.W.F., A.C.A.C., S.E.L., and J.L.J. designed research;S.W.F., A.C.A.C.,M.E.L., M.A.S., D.R.S. J.R.C., and S.E.L. performed research; S.W.F., A.C.A.C., R.R.S., M.E.L., M.A.S., J.R.C., S.E.L., and J.L.J. analyzed data; S.W.F., A.C.A.C., S.E.L., and J.L.J. wrote the paper.

This work was funded by a National Institutes of Health Office of the Director New Innovator Award DP2 OD001734 and by a gift from the Robert A. and Rene E. Belfer Family Foundation (J.L.J.). A.C.A.C. was supported by National Institute of Aging Biology of Aging training grant T32 AG000183 and by a Gates Millennium Scholarship. S.E.L., M.A.S., and M.E.L. are supported by the National Institute of Health (R00-AG031293, R01-NS033249) and by startup funds from the University of Minnesota Medical Foundation. We thank Bryan Song and Yuanyuan Zhang for animal care, Rich Paylor for advice on behavioral testing, Phil Jones for chemical analysis of the commercial GSI synthesis, and Kim Tolias and Shalaka Mulherkar for advice and reagents to analyze cofilin changes.

*S.W.F. and A.C.A.C. contributed equally to this work.

The authors declare no competing financial interests.

Correspondence should be addressed to Joanna L. Jankowsky, Baylor College of Medicine, BCM295, One Baylor Plaza, Houston, TX 77030. E-mail: jankowsk@bcm.edu.

DOI:10.1523/JNEUROSCI.0572-14.2014

Copyright $\odot 2014$ the authors $\quad 0270-6474 / 14 / 347871-15 \$ 15.00 / 0$
}

preventative active immunization (Janus et al., 2000; Morgan et al., 2000), while subsequent studies using passive immunization or $\gamma$-secretase inhibitors (GSIs) suggested that decreasing soluble $\mathrm{A} \beta$ and oligomeric assemblies was sufficient to restore cognitive function (Dodart et al., 2002; Kotilinek et al., 2002; Comery et al., 2005; Lee et al., 2006). However, many of these studies either tested before amyloid formation (Martone et al., 2009; Fukumoto et al., 2010; Balducci et al., 2011; Mitani et al., 2012; Zago et al., 2012), or used chronic treatments that affected plaque burden (Wilcock et al., 2004, 2006; Hartman et al., 2005; Chang et al., 2011). To date, only a limited number of studies have sought to distinguish the contribution made by different pools of $A \beta$ to cognitive impairments in mouse models of AD (Dodart et al., 2002; Comery et al., 2005; Lee et al., 2006; Melnikova et al., 2013; Mitani et al., 2013). However, most of these studies relied on a single behavioral measure to evaluate cognitive efficacy, and none examined recovery at the level of neuronal structure or function.

Both soluble and insoluble forms of $\mathrm{A} \beta$ can dramatically affect neuronal structure and function. Axons passing near amyloid plaques develop large distended swellings of ubiquitinated aggregates separated by domains that are abnormally thin and tortuous (Le et al., 2001; D’Amore et al., 2003; Stokin et al., 2005). In 
addition to these gross morphological changes in neighboring neurons, amyloid formation is associated with alterations in both local and long-distance neuronal signaling. Amyloid-bearing animals show diminished signal transmission between hemispheres with reduced response precision (Stern et al., 2004). Subsets of neurons in the vicinity of fibrillar deposits become hyperactive, while neighboring astrocytes develop spontaneous calcium waves uncoupled from local network activity (Busche et al., 2008; Kuchibhotla et al., 2008, 2009). The physical response to soluble oligomeric $\mathrm{A} \beta$ is considerably more subtle than the reaction to insoluble deposits, although no less consequential. Mounting evidence suggests that oligomeric $\mathrm{A} \beta$ in forms ranging from dimers and trimers to larger oligomers and protofibrils can be potently synaptotoxic (Wilcox et al., 2011; Larson and Lesne, 2012). In vitro application of naturally secreted oligomeric preparations causes rapid loss of dendritic spines and deficits in synaptic plasticity, while intracranial injection of similar preparations impairs learning and memory (Wilcox et al., 2011; Larson and Lesne, 2012). Together, these studies suggest a complex relationship between soluble and insoluble forms of $\mathrm{A} \beta$, alterations in neuronal structure and function, and resulting cognitive decline.

We sought to dissect this relationship using a unique mouse model in which the expression of transgenic APP and consequent overproduction of $A \beta$ could be arrested by treatment with doxycycline (dox). In past work, we have shown that suppressing transgenic APP expression after amyloid onset stops further plaque deposition while having little effect on pre-existing amyloid (Jankowsky et al., 2005; Wang et al., 2011). Here, we use this system to test the potential for synaptic and cognitive recovery following acute reduction of transgenic $\mathrm{APP} / \mathrm{A} \beta$ in the continued presence of amyloid plaques. By modulating the levels of APP and soluble $A \beta$ independently from amyloid load, we demonstrate significant functional and structural restoration, suggesting that substantial therapeutic benefit may be possible by reducing further production of $\mathrm{A} \beta$ without removing amyloid that has already formed.

\section{Materials and Methods}

Mice

The tet-responsive APP transgenic line 102 (tetO-APPswe/ind 102; MMRRC stock \# 034845-JAX; Jankowsky et al., 2005) and the tetactivator line B CaMKII $\alpha$-tTA (Jackson Laboratories \#3010; Mayford et al., 1996) were independently backcrossed to C57BL/6J for $>25$ generations before being intercrossed for these studies. The resulting double transgenic male offspring were then mated with wild-type FVB females to produce experimental cohorts on a FVBB6 F1 background.

Dox administration. All mice used in this study were raised on dox to suppress transgene expression during postnatal development. We have previously shown this strategy to ameliorate locomotor hyperactivity and normalize body weight of double transgenic animals, permitting reliable cognitive testing (Rodgers et al., 2012). Offspring were started on dox 1-3 $\mathrm{d}$ after birth by placing nursing mothers on medicated chow, formulated to $50 \mathrm{mg} / \mathrm{kg}$ dox (Purina Mills TestDiet \#5APL). At weaning, mice were maintained on dox until 6 weeks of age (Purina Mills TestDiet \#5SBA).

All mice were returned to regular chow for the following 6 months, allowing APP/tetracycline transactivator (TTA) animals to develop a moderate amyloid load. To test the potential cognitive benefit of shortterm APP suppression, at 7.5 months half of the mice were treated with dox for 2 weeks before behavioral testing and were maintained on dox until harvest.

During the course of this study, we discovered that the lot of chow we had purchased for postnatal treatment provided submaximal transgene suppression (80\% suppression rather than the $90-95 \%$ we expected at this dose), so therapeutic administration at 7.5 months was done by administering dox in the drinking water at a dose of $50 \mu \mathrm{g} / \mathrm{ml}$ supplemented with $5 \%$ sucrose to mask the bitter taste.

GSI administration. A separate cohort of age-matched mice that had also expressed transgenic APP for 6 months was treated with GSI to confirm that behavioral recovery attained by transgene suppression with dox was due to reduction of A $\beta$. LY411575 was administered either in drinking water at a concentration of $40 \mu \mathrm{g} / \mathrm{ml}$ (GSI stock dissolved at 100 $\mathrm{mg} / \mathrm{ml}$ in DMSO/ethanol to yield a working solution containing $1 \%$ DMSO and $0.8 \%$ ethanol) or through the chow at a concentration of 25 $\mathrm{mg} / \mathrm{kg}$ (BioServ Rodent Diet \#156166), in both cases to deliver an estimated dose of $5 \mathrm{mg} / \mathrm{kg} / \mathrm{d}$. Behavioral analysis began $5 \mathrm{~d}$ after treatment started.

\section{Behavioral assays}

Behavioral testing began at 8 months of age and included open field, Morris water maze (MWM), radial arm water maze (RAWM), and contextual fear conditioning (CFC). Animals were handled for $3 \mathrm{~d}$ before the start of behavioral testing. Locomotor activity was assessed on day 1 , followed by MWM training on days 2-10, and RAWM training on day 11. Mice were allowed a $2 \mathrm{~d}$ rest period before fear conditioning training on day 14, which was followed by a retention test $24 \mathrm{~h}$ later. All animal experiments were reviewed and approved by the Baylor College of Medicine Institutional Care and Use Committee.

Open-field assessment. Locomotor activity was assessed in white acrylic open-top boxes $(46 \times 46 \times 38 \mathrm{~cm})$ in a room lit by indirect white light. Activity was recorded for $30 \mathrm{~min}$ and analyzed using the ANY-maze Video Tracking System (Stoelting).

MWM. MWM testing was conducted in a circular tank measuring 58 $\mathrm{cm}$ high and $122 \mathrm{~cm}$ in diameter. The water level was $20 \mathrm{~cm}$ from the top of the tank and made opaque using nontoxic white paint. Water temperature was maintained between 21 and $23^{\circ} \mathrm{C}$. The room was lit with indirect white light and trials were recorded and tracked using ANY-maze Video Tracking System.

Before the start of acquisition training, mice received $1 \mathrm{~d}$ of training in a straight swim channel to acclimate them to the water and check for motor deficits. Mice received eight trials with a $15 \mathrm{~min}$ intertrial interval (ITI) in a channel constructed of white acrylic and measuring $107 \times 56$ $\times 14 \mathrm{~cm}$, which was placed in the center of pool. Visible cues were removed from the room during straight swim shaping trials. Mice were allowed $60 \mathrm{~s}$ to reach a submerged platform on the opposite side of the channel. Mice that failed to reach the platform were guided to the location by the experimenter. Mice were allowed to stay on the platform for $15 \mathrm{~s}$ before being removed from the water, dried, and returned to their home cage under an infrared lamp between trials.

Acquisition training in the MWM consisted of four trials per day with a 15 min ITI. Each training session ended with a short-term memory probe. A square platform $(10 \times 10 \mathrm{~cm})$ covered in nylon mesh for traction was located $1 \mathrm{~cm}$ below the surface in the NE quadrant of the maze, half way between the side and the center of the pool. Mice were placed in the maze facing the wall at each of four cardinal start locations and allowed $60 \mathrm{~s}$ to locate the hidden platform. As with straight swim, animals that failed to locate the platform in the allotted time were gently guided there by the experimenter. Mice were allowed to stay on the platform for $15 \mathrm{~s}$ before being returned to their home cage between trials. Following the 4 training trials, the platform was removed from the maze for an immediate probe trial. Animals were placed in the tank half way between the cardinal points (SW, NW, SE, and NE) and allowed $45 \mathrm{~s}$ to navigate the maze. Proximity to target, percentage time, and percentage path spent in each quadrant were calculated along with the number of times the animal crossed the platform location compared with the other three potential platform locations (in the SW, NW, and SE quadrants). Mice were trained to a performance criterion during probe trials of $\geq 35 \%$ path in the correct quadrant and at least $40 \%$ of total platform crossings over the correct site compared with other possible platform locations.

When mice reached criterion, they were retired from further MWM training, but given a final long-term memory probe $24 \mathrm{~h}$ after reaching criterion. Mice were trained for a maximum of $7 \mathrm{~d}$. After all mice either reached criterion or completed $7 \mathrm{~d}$ of training, each was given one additional "refresher" day of training (four trials) with probe test to ensure 
equivalent performance between groups before starting RAWM training. During this refresher training, performance in our cohorts was identical both between genotypes $\left(F_{(2,52)}=0.34, p>0.05\right)$ and treatment groups $\left(F_{(1,52)}=0.74, p>0.05\right)$. Thus, this procedure ensured that all mice were trained to a similar performance level before moving onto RAWM testing in the same room.

RAWM. The day following MWM refresher training, mice received $1 \mathrm{~d}$ of RAWM training consisting of eight trials with a 15 min ITI. The RAWM was created by installing clear Plexiglas triangular inserts into the existing water maze pool $(41.25 \mathrm{~cm}$ on each side $\times 50 \mathrm{~cm}$ high $)$, which resulted in six open arms joined at the center. Each arm measured $20 \mathrm{~cm}$ wide $\times 34 \mathrm{~cm}$ long, and the water was maintained at a depth of $38 \mathrm{~cm}$. The platform was located $3 \mathrm{~cm}$ from the end of one arm and submerged $1 \mathrm{~cm}$ below the water's surface. Mice were placed into a different arm at the beginning of each trial, with the order of starting positions pseudorandomly selected before training such that no trial began in an arm adjacent to the previous start position. Mice were allowed $60 \mathrm{~s}$ to navigate the maze. If a mouse failed to locate the platform in the allotted time, it was gently guided to there by the experimenter and allowed to remain on the platform for $15 \mathrm{~s}$ before being returned to its home cage between trials. Latency to locate the platform, swim path length, and number of working memory errors (re-entries into a previously visited arm) were calculated for each trial. Trial 1 scores were excluded from analysis due to the inflated error rate as animals learned the new procedure. Data from trials 2-8 was averaged to provide a performance index for overall RAWM learning. After the final training trial, animals were tested with a short-term probe trial in which the platform was removed and animals were allowed $45 \mathrm{~s}$ to navigate the maze. Percentage time and path spent in the target arm were calculated and compared among treatment groups.

CFC. Two days after RAWM testing, mice were trained in CFC using a near-infrared video fear conditioning system (Med Associates). Conditioning boxes $(30.5 \times 24 \times 21 \mathrm{~cm})$ with a stainless steel grid floor were located inside sound-attenuating chambers and indirectly lit from above. Movement was recorded by a video camera mounted inside the soundattenuating chamber and analyzed using Video Freeze software (Med Associates). Motion threshold was set to 19 arbitrary units (a.u.) and the minimum freeze duration to $1 \mathrm{~s}$. Chambers and grid floors were cleaned with a $20 \%$ ethanol solution after each trial.

During conditioning, mice were allowed to freely explore the chambers for $2 \mathrm{~min}$ before receiving a $1 \mathrm{~s} 0.8 \mathrm{~mA}$ footshock. After a $2 \mathrm{~min}$ interval, mice received a second $1 \mathrm{~s} 0.8 \mathrm{~mA}$ footshock. Mice remained in the chamber for $1 \mathrm{~min}$ after second footshock before being returned to their home cage. Twenty-four hours later, animals were returned to the same conditioning box for a $5 \mathrm{~min}$ retention test. The duration of immobility was recorded and used as an index of learning.

\section{Tissue harvest}

One week after behavioral testing was completed, mice were killed by sodium pentobarbital overdose and transcardially perfused with ice-cold PBS containing $10 \mu \mathrm{g} / \mathrm{ml}$ heparin. Brains were removed and hemisected along the midline. One hemisphere was dissected to isolate the cortex and hippocampus, which were snap frozen for biochemistry, and the other hemisphere was immersion fixed in $4 \%$ PFA at $4^{\circ} \mathrm{C}$ for $48 \mathrm{~h}$. Brains were cryoprotected in $30 \%$ sucrose at $4^{\circ} \mathrm{C}$. Tissue was sectioned at $35 \mu \mathrm{m}$ in the sagittal plane using a freezing sliding microtome, then stored in cryoprotectant $(0.1 \mathrm{~m}$ phosphate buffer, $\mathrm{pH} 7.4,30 \%$ ethylene glycol, and $25 \%$ glycerol) at $-20^{\circ} \mathrm{C}$ until use.

\section{Histology}

Campbell-Switzer silver stain. A detailed protocol for this stain can be found at the NeuroScience Associates website (http://www.neuroscienceassociates.com/ Documents/Publications/campbell-switzer_protocol.htm).

Thioflavine-S histology. A 1/12 series of sections spaced at $420 \mu \mathrm{m}$ intervals were stained for thioflavine. Sagittal $35 \mu \mathrm{m}$ sections were rinsed, mounted onto SuperFrost Plus slides, and dried overnight. Sections were rehydrated in running tap water, incubated for $10-15 \mathrm{~min}$ in $0.25 \%$ potassium permanganate, followed by $5 \mathrm{~min}$ in $1 \%$ potassium metabisulfite/ $1 \%$ oxalic acid, before staining in $0.02 \%$ thioflavine-S (Sigma \#T1892) for $8 \mathrm{~min}$. Staining was differentiated in $80 \%$ ethanol, followed by running tap water. Sections were dehydrated through xylene and coverslipped with Permount.

Synaptophysin immunofluorescence and thioflavine-S histology. A 1/24 series of sections spaced at $840 \mu \mathrm{m}$ intervals were immunostained for synaptophysin and counterstained for thioflavine. Sagittal $35 \mu \mathrm{m} \mathrm{sec}-$ tions were rinsed, blocked in TBS plus $0.3 \%$ Triton X-100 (TBST) and $5 \%$ normal goat serum for $1 \mathrm{~h}$ at room temperature, and stained with rabbit anti-synaptophysin antibody (\#AB9272; Millipore) diluted 1:1000 in blocking solution overnight at $4^{\circ} \mathrm{C}$. Sections were then washed with TBS and incubated with Alexa 568-conjugated secondary antibody (goat anti-rabbit IgG \#A11011; Invitrogen) diluted 1:500 in block at room temperature for $1 \mathrm{~h}$. Sections were washed with TBS before being counterstained with $0.002 \%$ thioflavine-S (\#T1892; Sigma) diluted in TBS at room temperature for $8 \mathrm{~min}$. After two $1 \mathrm{~min}$ washes in $50 \%$ ethanol followed by several washes in TBS, sections were mounted on SuperFrost Plus slides and coverslipped with Vectashield mounting medium (Vector Laboratories).

$A \beta$ immunohistochemistry. A $1 / 12$ series of sections spaced at $420 \mu \mathrm{m}$ intervals were rinsed with TBS, pretreated with $88 \%$ formic acid for 1 min at room temperature, and blocked with TBST containing 5\% normal goat serum before overnight incubation at $4^{\circ} \mathrm{C}$ with rabbit anti-human $\mathrm{A} \beta$ antibody (\#71-5800; Zymed/Invitrogen) diluted 1:500 in blocking solution. After several washes in TBS, sections were incubated with biotin-conjugated goat anti-rabbit secondary (Vectastain Elite ABC Kit, Rabbit IgG; Vector Laboratories) diluted 1:500 in blocking solution for $1 \mathrm{~h}$ at room temperature followed by HRP-avidin conjugate diluted 1:50 in TBS for $30 \mathrm{~min}$ at room temperature. Sections were developed with DAB (\#D4418; Sigma), then mounted, dehydrated, and coverslipped with Permount.

Quantification of amyloid burden. Amyloid burden was quantified using a custom macro written for Zeiss AxioVision 4.8 software as described previously (Wang et al., 2011). Color thresholds were used to identify amyloid plaques in high-resolution digital scans of $A \beta$ immunostained and thioflavine-S stained sections using a custom macro written with Zeiss AxioVision software. Background staining and shading artifacts were manually excluded from the analyses. The region of interest was specified by outlining the cortex or hippocampus and the area above threshold computed relative to total area. Three (A $\beta$ immunostain) or six sections (thioflavine-S) spaced at $420 \mu \mathrm{m}$ intervals were measured for each animal.

Quantification of synaptophysin. The area of synaptophysin immunostaining surrounding thioflavine-S-positive fibrillar plaques was measured using a custom script written in MATLAB (R2012b) to batch process two-channel fluorescence images in an unbiased and automated way. Two tissue sections spanning the frontal cortex were selected for analysis from each animal. Two nonoverlapping fields of view each centered on an isolated plaque of $43.56 \mu \mathrm{m}$ average diameter were photographed for each section. A single optical plane of $0.98 \mu \mathrm{m}$ in depth was collected from each field in the red (synaptophysin) and green (thioflavine) channels using an ApoTome structured illumination device (Carl Zeiss). At $40 \times$ magnification each field spanned an area of $222.2 \times 166.4 \mu \mathrm{m}$.

The first step in the automated script removed the area occupied by the thioflavine-positive plaque from the region of interest that would be used be used to measure synaptophysin. To accomplish this in an unbiased fashion, we binarized the grayscale thioflavine images using Otsu's method. The Otsu method works by calculating the threshold at which to divide the dataset into signal and background so that the variance in each of the resulting subsets is minimized. In this case, the method uses variance minimization to define the cutoff between thioflavine-positive pixels and thioflavine-negative pixels. Pixels above background defined the area of the plaque and were used as a mask to remove this region from the corresponding synaptophysin image. The masked synaptophysin images were then also binarized, again applying Otsu's method for determining the optimal threshold between signal and background. The script then calculated the area occupied by synaptophysin-positive pixels in each image, normalizing to the total area remaining after the region of thioflavine staining was removed. We have posted the script on MATLAB's 
File Exchange (http://www.mathworks.com/matlabcentral/fileexchange/ 39591).

\section{Immunoblotting}

APP, synapsin, and PSD95. Frozen cortical samples were prepared for Western blotting by sonication in $2 \%$ SDS plus $1 \times$ protease inhibitor cocktail (Sigma P8340) and then diluted 1:1 with $2 \times$ SDS-free RIPA buffer ( $2 \times$ PBS, $1 \%$ deoxycholate, $1 \%$ NP40, and 5 mM EDTA). For APP, $\sim 50 \mu \mathrm{g}$ of the resulting homogenate was separated on a $10.5-14 \%$ Tris$\mathrm{HCl}$ gel (Bio-Rad Criterion) and transferred to nitrocellulose. For synapsin and PSD95, $25 \mu \mathrm{g}$ of cortical homogenate was separated on a $4-15 \%$ Tris- $\mathrm{HCl}$ gel and transferred to nitrocellulose. Membranes were blocked in PBS plus $0.1 \%$ Tween 20 and 5\% nonfat dry milk for $1 \mathrm{~h}$ at room temperature. $\mathrm{APP} / \mathrm{A} \beta$ antibody $6 \mathrm{E} 10$ and $\mathrm{PSD} 95$ was used to probe the upper part of the blot; GAPDH was used to probe the lower part as a loading control. HRP-labeled secondary antibodies [goat anti-mouse IgG diluted 1:5000 (\#115-035-003; Jackson ImmunoResearch) and goat anti-chicken IgG diluted 1:10,000 (\#14-24-06; Kirkegaard \& Perry Laboratories)] were used to detect binding, and developed with Immobilon ECL Reagent (\#WBKLS0100; Millipore). Chemiluminescence was measured with a Fuji miniLAS-4000 system and quantified using MultiGauge software. After imaging, the blot was stripped by incubation for 30 min at $50^{\circ} \mathrm{C}$ in $50 \mathrm{~mm}$ Tris-HCl, $2 \%$ SDS, and $0.7 \% \beta$-mercaptoethanol and the upper portion reprobed for synapsin as above.

$A D F / c o f i l i n$ and PAK1. Frozen cortical samples were prepared for Western blotting by cellular fractionation described below. Approximately $50 \mu \mathrm{g}$ of the intracellular fraction was separated on a $4-15 \%$ Tris- $\mathrm{HCl}$ gel and transferred to nitrocellulose. Phosphorylated cofilin and PAK1 was probed first using rabbit anti-phospho-cofilin (1:500; \#3311; Cell Signaling Technology) or rabbit anti-phospho-PAK1 (1: 1000; \#2601; Cell Signaling Technology) in conjunction with chicken anti-GAPDH (1:10,000; \#AB3202; Millipore) as a loading control. After chemiluminescence was measured, blots were stripped as described above and reprobed for total levels of protein using rabbit anti-cofilin diluted 1:1000 (\#5175; Cell Signaling Technology) or rabbit anti-PAK1 (1:1000; \#2602; Cell Signaling Technology).

Oligomeric $A \beta$. Frozen cortical samples were fractionated by a fourstep extraction method. Extraction began by mechanical homogenization in $250 \mu$ l of $50 \mathrm{~mm}$ Tris-HCl, pH 7.6, 0.01\% NP-40, $150 \mathrm{~mm} \mathrm{NaCl}, 2$ mM EDTA, $0.1 \%$ SDS, and $1 \times$ PPP [ 1 mM phenylmethylsulfonyl fluoride, $2 \mathrm{~mm} 1,10$-phenanthroline monohydrate, and $1 \times$ protease inhibitor cocktail] using five passes through a $1 \mathrm{ml}$ syringe with a 20 gauge needle. Soluble, extracellular-enriched proteins were collected from the supernatant of this extract following $10 \mathrm{~min}$ at $800 \times \mathrm{g}, 4^{\circ} \mathrm{C}$. The remaining pellet was then mechanically dissociated by trituration with an Eppendorf micropipette in $250 \mu \mathrm{l}$ of $50 \mathrm{~mm}$ Tris- $\mathrm{HCl}, \mathrm{pH} 7.4,150 \mathrm{~mm} \mathrm{NaCl}$, $0.1 \%$ Triton X-100, and $1 \times$ PPP. Cytoplasmic proteins were collected from the supernatant of this extract following $90 \mathrm{~min}$ at $16,100 \times \mathrm{g}, 4^{\circ} \mathrm{C}$. The remaining pellet was then triturated with a micropipette followed by passive lysis on a rotating platform for $15 \mathrm{~min}$ at $4^{\circ} \mathrm{C}$ in $250 \mu \mathrm{l}$ of $50 \mathrm{mM}$ Tris-HCl, pH 7.4, 150 mm NaCl, 0.5\% Triton X-100, 1 mm EGTA, 3\% SDS, $1 \%$ deoxycholate, and $1 \times \mathrm{PPP}$. Membrane-enriched proteins were collected from the supernatant of this extract following $90 \mathrm{~min}$ at $16,100 \times g, 4^{\circ} \mathrm{C}$. The membrane-enriched fraction was clarified by 60 $\mathrm{min}$ at $100,000 \times \mathrm{g}$. Each fraction was depleted of endogenous immunoglobulins by sequential incubation for $1 \mathrm{~h}$ at $4^{\circ} \mathrm{C}$ with $50 \mu \mathrm{l}$ of protein A-Sepharose, Fast Flow followed by $50 \mu$ of protein G-Sepharose, Fast Flow (GE Healthcare Life Sciences). All supernatants were clarified by 90 $\min$ at $16,100 \times g$ before Western blot analysis.

One hundred micrograms of protein per sample was electrophoresed on $10-20 \%$ SDS-polyacrylamide Tris-tricine gels (Bio-Rad). Proteins were transferred to nitrocellulose and membranes boiled in PBS for 5 min. Membranes were blocked in TBSTw containing $5 \%$ bovine serum albumin (\#A3803; Sigma, $>98 \%$ grade) for $2 \mathrm{~h}$ at room temperature, and probed with either 6E10 (\#SIG-39320; Covance) or biotinylated-6E10 (\#SIG-39340; Covance) diluted 1:2500 in blocking solution. A duplicate set of gels loaded with $50 \mu \mathrm{g}$ or $20 \mu \mathrm{g}$ protein was blotted and probed for $\alpha$-synuclein (extracellular fraction; Covance \#SIG-39720 diluted 1:5,000) or actin (membrane fraction; Sigma \#A2066 diluted 1:10,000) as internal controls to demonstrate equal protein concentrations across samples. Primary antibodies were detected using anti-IgG conjugated with either biotin or infrared dyes (LI-COR Biosciences). When biotinconjugated antibodies were used, DyLight800-conjugated NeutrAvidin (\#22853; Thermo Scientific) was added to amplify the signal. Blots were imaged with an Odyssey detection system (LI-COR Biosciences). Densitometry analyses were performed using OptiQuant software (Packard Bioscience) or Image Studio software (LI-COR Biosciences).

\section{Dot blotting}

Two micrograms of extracellular-enriched or membrane-associated protein lysates were mixed with sterile filtered deionized water in a total volume of $2.5 \mu \mathrm{l}$. Each sample was then adsorbed onto a nitrocellulose membrane until dry. Following a brief activation in 10\% methanol/TBS, the membrane was boiled in PBS to enhance antigen detection as previously described (Sherman and Lesné, 2011). Membranes were blocked in TBS containing $5 \%$ bovine serum albumin for $60 \mathrm{~min}$, then moved to primary antibody 6 E10 (1:2500) and A11 (1:2000; a kind gift from Rakez Kayed, University of Texas Medical Branch, Galveston, TX) for overnight incubation at $4^{\circ} \mathrm{C}$. Following several washes, anti-mouse IgGIR800 $(1: 100,000)$ and anti-rabbit IgG-IR680 $(1: 150,000)$ secondary antibodies were used for detection with a Li-Cor Odyssey imager. All steps were performed without detergent to enhance A11 binding of oligomeric species as previously reported (Lesné et al., 2006).

\section{Immunoprecipitation}

Two hundred micrograms of protein extract was diluted to $1 \mathrm{ml}$ with dilution buffer ( $50 \mathrm{~mm}$ Tris- $\mathrm{HCl}, \mathrm{pH} 7.4$, and $150 \mathrm{~mm} \mathrm{NaCl}$ ) and incubated with $5 \mu \mathrm{g}$ of $6 \mathrm{E} 10$ overnight at $4^{\circ} \mathrm{C}$. The following day, $50 \mu \mathrm{l}$ of Protein G-Sepharose, Fast Flow (GE Life Sciences) was added [mixed 1:1 (v:v) with immunoprecipitation (IP) buffers A and B; Sherman and Lesné, 2011] and incubated at $4^{\circ} \mathrm{C}$ for $2 \mathrm{~h}$. The beads were washed twice in $1 \mathrm{ml}$ of dilution buffer and proteins were eluted by boiling in $30 \mu \mathrm{l}$ of SDS-PAGE loading buffer.

In vivo microdialysis. Mice were unilaterally implanted with a $38 \mathrm{kDa}$ molecular weight cutoff microdialysis probe ( $2 \mathrm{~mm}$ BR-style; Bioanalytical Systems) by placing the probe tip into the hippocampus at a 12 degree angle $-3.1 \mathrm{~mm}$ from bregma, $-2.5 \mathrm{~mm}$ from midline, and $3.2 \mathrm{~mm}$ below the dura (Cirrito et al., 2003, 2011). Microdialysis perfusion buffer consisted of $4 \%$ albumin in artificial CSF at a flow rate of $1.0 \mu \mathrm{l} / \mathrm{min}$. Animals were allowed to recover for $6-8 \mathrm{~h}$ after probe insertion, then six interstitial fluid (ISF) A $\beta$ measurements were taken over a $6 \mathrm{~h}$ period. The mean concentration of exchangeable $A \beta$ during this $6 \mathrm{~h}$ period was defined as the baseline ISF $A \beta$ concentration for each mouse. After baseline $\mathrm{A} \beta$ levels were established, mice were treated with dox at a concentration of $50 \mu \mathrm{g} / \mathrm{ml}$ in their drinking water for $4 \mathrm{~d}$. During this time, microdialysis samples were continuously collected every $1-3 \mathrm{~h}$ into a refrigerated fraction collector. Following the final collection, samples were assayed for $\mathrm{A} \beta \mathrm{x}-40$ and $\mathrm{A} \beta \mathrm{x}-42$ by sandwich ELISA using an $\mathrm{A} \beta 40$ $(\mathrm{mHJ} 2)$ or $\mathrm{A} \beta 42$-specific antibody (mHJ7.4) to capture the peptide followed by a biotinylated central domain anti-A $\beta$ antibody ( $\mathrm{mHJ} 5.1$ ) for detection (Cirrito et al., 2011). The concentration of ISF A $\beta$ in each sample was normalized to the baseline $A \beta$ concentration for each mouse. At the end of the experiment, the brains were harvested and processed for histological verification of probe placement.

\section{Statistical analysis}

Data were analyzed using one-way or two-way ANOVA or $t$ test where appropriate. All post hoc comparisons were conducted using Bonferroni correction. Statistical tests for behavioral experiments were conducted using SPSS Statistics 20 (IBM). Statistical tests for biochemical and histological experiments were conducted using Prism 6.0 (GraphPad). Graphs were created using Prism 6.0 and display group means \pm SEM.

\section{Results}

Dox rapidly suppresses transgenic APP expression, decreases exchangeable $A \boldsymbol{\beta}$ levels, and stabilizes amyloid load

We studied a temporally controlled transgenic mouse model in which the TTA activates expression of human $\mathrm{APP}_{\text {swe/ind }}$ within 
A The tet-off system

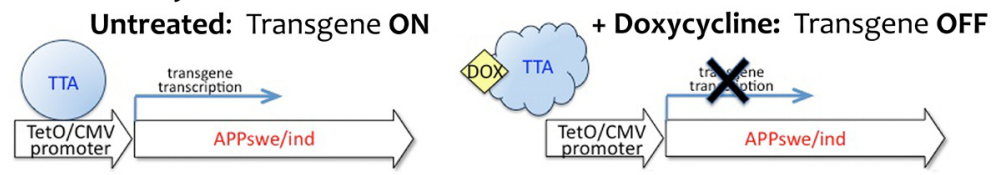

B Experimental design

Transgene suppression studies:

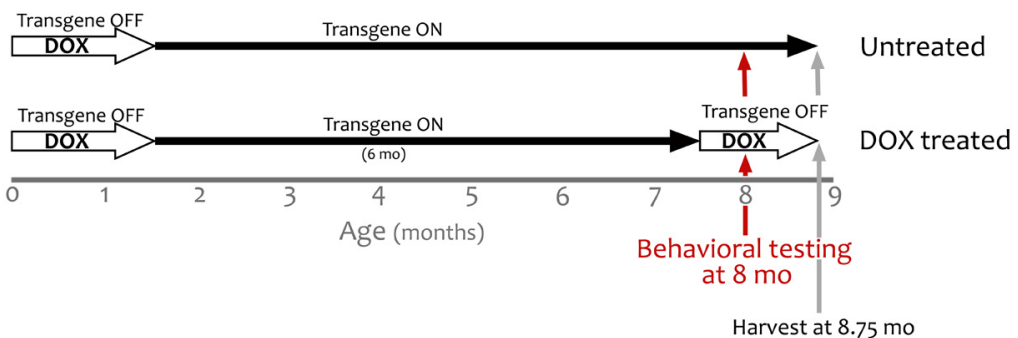

Figure 1. Using the tet-off system to initiate APP/A $\beta$ overexpression in the adult and therapeutically suppress it after amyloid onset. $A$, Under normal conditions, TTA binds to its recognition sequence in the hybrid tet $0 / C M V$ promoter to activate transcription of the downstream transgene (APPswe/ind). Upon binding dox, TTA undergoes a conformational switch that prevents DNA binding and stops further transcription of transgenic mRNA. $\boldsymbol{B}$, The tet-off APP model uses the CaMKIll $\alpha$ promoter to control the expression of TTA, thereby limiting transgenic APP to the forebrain. Under normal conditions, expression from this promoter begins during late embryogenesis and transgenic APP is present at high levels by birth. In the current experiments, dox was used to delay transgene expression until adulthood (P41-P43). Transgenic APP expression was initiated at 6 weeks of age by removing dox from the diet, and remained active for the next 6 months. Therapeutic intervention to suppress further transgene expression with dox or prevent $A \beta$ release with GSI began at 7.5 months of age. One cohort of dox-treated mice was harvested after just 2 weeks of treatment to establish the amyloid load present at the outset of behavioral testing. Behavioral testing in the remaining dox-treated animals continued for another 3 weeks; afterward all mice were harvested for histology and biochemical analysis.

A

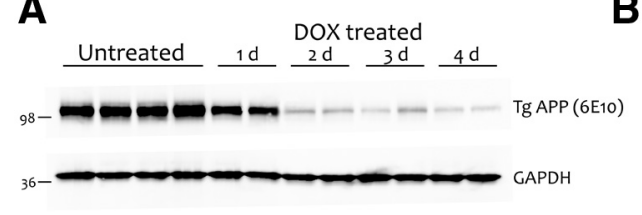

C

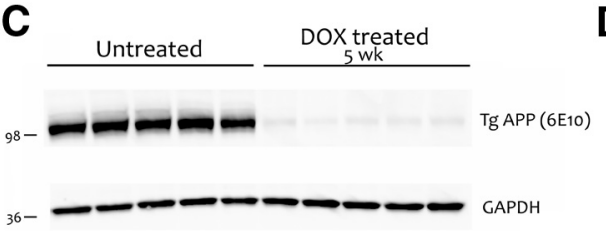

B

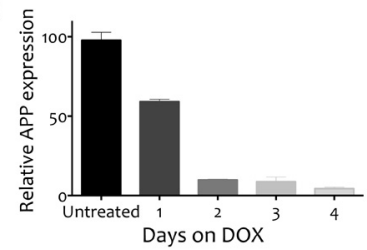

D

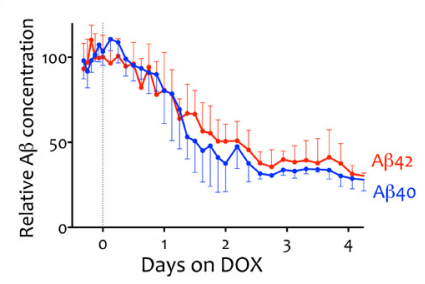

Figure 2. Dox treatment induces rapid, persistent suppression of transgenic APP and a concomitant decrease in ISF A $\beta$ concentration. $\boldsymbol{A}$, Western blot showing APP suppression in APP/TTA mice following $1-4 \mathrm{~d}$ of dox treatment. Anti-A $\beta$ antibody $6 \mathrm{E} 10$ was used to detect transgenic APP in cortical homogenates. GAPDH was probed as an internal control. $\boldsymbol{B}$, Quantification of the immunoblot shown in $A$ reveals that transgenic APP levels are reduced by $40 \%$ within $1 \mathrm{~d}$ of dox treatment and by $90 \%$ within $2 \mathrm{~d}$. C, Immunoblot analysis of transgenic APP in cortical homogenates from behaviorally tested mice demonstrates that transgene suppression was maintained at $>90 \%$ throughout cognitive testing ( $n=5$ per condition). $D$, Microdialysis of hippocampal ISF reveals that following a $1 \mathrm{~d}$ delay, $A \beta$ concentration dropped at approximately the same rate and to a similar extent as transgenic APP. The concentration of both $A \beta 40$ (blue; $n=5$ ) and $A \beta 42$ (red; $n=4$ ) were decreased by $>50 \%$ within $2 \mathrm{~d}$ of dox treatment and $70 \%$ by $3 \mathrm{~d}$.

forebrain neurons. In this system, TTA acts as an artificial transcription factor specific for the tetO promoter controlling transgenic APP. On administration of dox, TTA undergoes a conformational change that prevents it from binding DNA and thereby arrests further expression of transgenic APP (Fig. 1A). We took advantage of this system to test whether acutely reducing production of transgenic APP and $A \beta$ is sufficient to rescue cognitive impairments after the onset of amyloid deposition. Be- cause we have previously shown that APP overexpression during postnatal development causes severe locomotor hyperactivity (Rodgers et al., 2012), here we used mice in which transgene expression was delayed until adulthood (Fig. 1B). Transgene expression was initiated at 6 weeks of age and continued for an additional 6 months to produce moderate amyloid deposition in APP/TTA double transgenic mice by the age of behavioral testing. In past work we have shown that amyloid formed during this period of APP overexpression persists for $>18$ months after transgene suppression (Jankowsky et al., 2005; Wang et al., 2011; J.L. Jankowsky, unpublished data).Together, this model provides a way to controllably arrest further production of transgenic APP and soluble $\mathrm{A} \beta$ without affecting pre-existing amyloid.

We first examined the rate and efficiency of transgenic APP suppression in the tet-off model using mice of approximately the same age as our behaviorally tested animals, but which were killed within $1-4 \mathrm{~d}$ of starting dox treatment. Western blotting of transgenic APP levels across days revealed that APP expression was reduced by $40 \%$ within $24 \mathrm{~h}$ of dox treatment and reached $90 \%$ suppression at $48 \mathrm{~h}$ (Fig. 2A,B). We confirmed that APP suppression could be chronically maintained at this level by measuring transgenic APP expression in behaviorally tested animals treated for 5 weeks on dox, as shown by comparing APP expression in mice that were harvested after 5 weeks of differential treatment (Fig. 2C). These mice showed the same degree of suppression as animals harvested after $2 \mathrm{~d}$ on dox, with transgenic APP levels $<10 \%$ that of untreated mice $(t=102.1, \mathrm{df}=8, p<$ $0.001)$. These results indicate that APP suppression had stabilized at $>90 \%$ before behavioral testing and remained at this level throughout our experiments.

We then used in vivo microdialysis to ascertain that soluble $\mathrm{A} \beta$ levels in hippocampal ISF were reduced by dox treatment along with transgenic APP (Fig. 2D; Cirrito et al., 2003). Before dox treatment, $\mathrm{A} \beta 40$ levels averaged $742 \pm 106 \mathrm{pg} / \mathrm{ml}$ $(n=5)$ and $\mathrm{A} \beta 42140 \pm 24 \mathrm{pg} / \mathrm{ml}(n=4)$.

The concentration of both peptides quickly declined with dox treatment. Exchangeable ISF A $\beta 40$ and A $\beta 42$ levels dropped by $>50 \%$ within $48 \mathrm{~h}$ of dox treatment (post hoc test, $p<0.001$ ), and reached nearly $70 \%$ suppression compared with baseline ISF $A \beta$ levels by $72 \mathrm{~h}$ (post hoc test, $p<$ 0.0001 ). The difference between the extent of APP reduction and that of $A \beta$ is likely due to the continued release of peptide from nearby plaques even after further production is suppressed. Recent work suggests that the concentration of ISF A $\beta$ is deter- 
mined by a combination of existing peptide in exchange with insoluble aggregates and de novo synthesis (Hong et al., 2011; Takeda et al., 2013). Consistent with this explanation, when the reduction of $\mathrm{A} \beta$ was tested in young, predeposit animals from a line similar to the one studied here, both transgenic APP and PBSsoluble $A \beta 42$ dropped by $>95 \%$ after transgene suppression (Jankowsky et al., 2005). Thus, dox treatment may be equally effective at reducing new $\mathrm{A} \beta$ synthesis as transgenic APP, but the impact on ISF $A \beta$ is likely offset by peptide shedding from pre-existing aggregates. In this regard, the outcome of transgene suppression is precisely what has been demonstrated in noncontrollable models using pharmacologic secretase inhibitors (Hong et al., 2011).

Although transgenic APP and ISF A $\beta$ levels quickly declined with dox treatment, our past work with this system has shown that suppressing APP expression halts amyloid growth without plaque clearance (Jankowsky et al., 2005; Wang et al., 2011). Given this, we predicted that dox-treated animals would approximately maintain the same amyloid burden as age-matched untreated controls, at least for short periods of time. We confirmed that the area of total amyloid detected by silver staining or $\mathrm{A} \beta$ immunohistochemistry (fibrillar + diffuse; Fig.

$3 A, B)$, and specifically that of fibrillar amyloid detected by thioflavine-S staining (Fig. $3 C$ ), was identical in dox-treated and untreated mice following 2 weeks of differential treatment $(p>$ 0.05 for both cortex and hippocampus; Fig. 3D). We then designed our behavioral experiments based on this time frame so that the two groups began testing with identical plaque burden. Over the next 3 weeks of differential treatment, fibrillar amyloid remained unchanged in both cortex and hippocampus and was indistinguishable between treatment groups at the end of behavioral testing (two-way ANOVA, main effect of treatment, $F_{(1,26)}$ $=0.653$, main effect of time, $F_{(1,26)}=0.004$, both $\left.p>0.05\right)$. Total amyloid load detected by $\mathrm{A} \beta$ immunostaining increased more noticeably between 2 and 5 weeks of differential treatment due to accumulation of diffuse deposits in untreated mice. We have previously shown that amyloid deposition in tet-off APP mice occurs rapidly at this stage of pathology, and the significant rise observed here over just a few weeks is not unexpected (Rodgers et al., 2012). At the conclusion of behavioral testing, the area of $A \beta$ immunostaining was significantly higher in untreated mice than in dox-treated mice for both cortex and hippocampus (two-way ANOVA, treatment $\times$ time interaction, $F_{(1,26)}=18.49, p<0.05$, Bonferroni post hoc test, $p<0.001$ for cortex at 5 weeks and $F_{(1,26)}$ $=8.44, p<0.05$, Bonferroni post hoc test, $p<0.01$ for hippocampus at 5 weeks). Thus, our findings suggest that the two groups began behavioral testing with identical amounts of fibrillar and total amyloid. Growth of diffuse plaques in untreated animals lead to an increase in total amyloid during this time, while fibrillar amyloid remained stable throughout behavioral testing in both dox- treated and untreated animals such that they ended the experiments with the same amount as they started.

\section{Acquisition of spatial reference memory is restored by short-} term suppression of transgenic APP

Our initial experiments demonstrated that 2 weeks of dox treatment allowed us to selectively lower ISF A $\beta$ levels while leaving deposited amyloid unchanged. We took advantage of this situation to test whether acute reduction of soluble $\mathrm{A} \beta$ was sufficient to normalize behavioral impairments in plaque-bearing animals.

Behavioral analysis began with an assessment of open-field activity to ensure that the APP/TTA mice did not display the locomotor hyperactivity described previously with this line (Rodgers et al., 2012). Open-field activity revealed no difference in total distance traveled $\left(F_{(5,51)}=1.025, p=0.413\right)$ or in locomotor speed between genotypes or treatment groups $\left(F_{(5,51)}=\right.$ $0.66, p=0.66)$, indicating that the APP/TTA mice used for this study were not hyperactive compared with their TTA and nontransgenic (NTG) siblings.

Having established that hyperlocomotion would not confound our behavior testing, we proceeded with a battery of cognitive tests designed to examine acquisition and recall of reference, working, and associative memory through a modified MWM, six-arm RAWM, and CFC, respectively. We modified the standard MWM to both improve our sensitivity for subtle performance differences, and to ensure that we could use the same room for subsequent RAWM training. We used a train-tocriteria version of the MWM, in which short-term memory probes at the end of each day of training were used to assess 
A

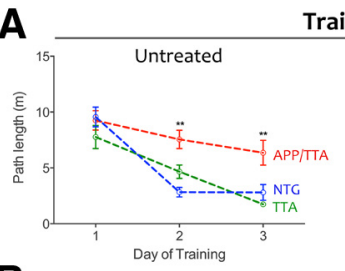

B

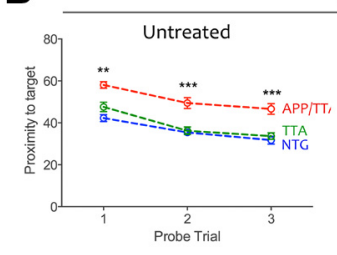

STM
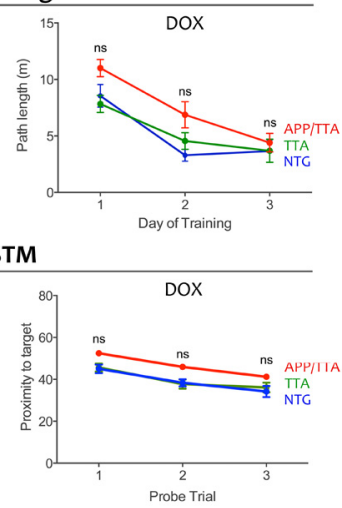

C

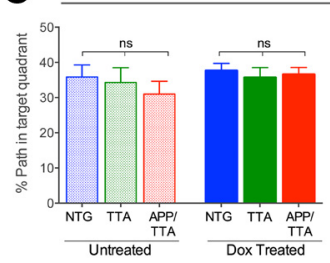

LTM

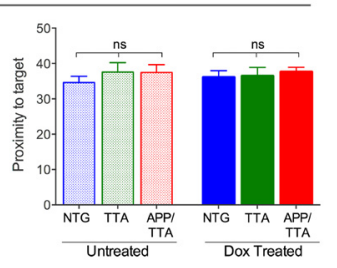

D
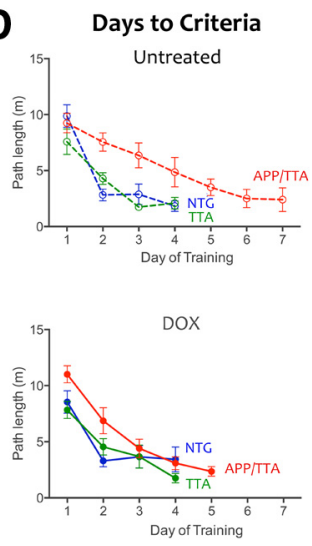

$\mathbf{E}$

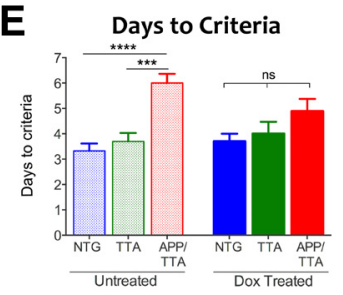

Figure 4. Acute suppression of APP/A $\beta$ results in partial recovery of spatial reference memory. $A$, Average path length required to reach the hidden platform on the first $3 \mathrm{~d}$ of MWM testing. Untreated APP/TTA mice $(n=10)$ perform significantly worse than NTG $\left(n=9 ;{ }^{* *} p<0.01\right)$ and TTA controls $\left(n=10 ;{ }^{* *} p<0.01\right)$ on days 2 and 3 of training (left). Transgene suppression with dox restored the performance of APP/TTA mice $(n=9)$ to that of NTG $(n=10)$ and TTA controls $(n=9$; right). B, Short-term memory (STM) probe trials were used to assess immediate recall at the end of each day. STM of untreated APP/TTA mice was worse than controls on the first $3 \mathrm{~d}$ of training ( $p<0.01$ for day 1 and $p<0.001$ for days 2 and 3 , left). Acute transgene suppression with dox improved immediate recall in APP/TTA mice to that of controls (right). $C$, Twenty-four hours after mice reached criteria performance, they were administered one final probe trial to assess long-term memory (LTM). Once all mice reached criterion performance, their long-term recall was identical across groups. Left, Shows percentage path in the trained quadrant; right shows proximity to target. $\boldsymbol{D}$, Average path length required to reach the hidden platform reflects the number of training days required to reach criteria performance for untreated (top) and dox-treated mice (bottom). $\boldsymbol{E}$, Untreated APP/TTA mice require more days to reach criterion than NTG $(p<0.0001)$ and TTA controls $(p<0.001)$. Following transgene suppression, all groups reached criteria performance in the same number of days.

spatial learning and decide if mice would proceed to a long-term probe trial or to additional training the following day. As illustrated below, this approach brought all of the mice to the same level of performance before they began RAWM testing. This allowed us to examine long-term memory independent from the rate of acquisition, and yielded days-to-criteria as an added measure of spatial learning.

Untreated APP/TTA mice demonstrated a clear impairment in acquisition of the MWM, swimming farther to locate the hidden platform during days 2 and 3 of training than either NTG or TTA controls $\left(F_{(2,102)}=9.98, p<0.001\right.$; post hoc, $p<0.001$ for NTG and $p<0.01$ for TTA; all $F$ values are from two-way RM-ANOVA including dox-treated groups discussed below; Fig. $4 A$, left). Short-term memory, examined by probe trials at the end of each training day, was also impaired in the untreated APP/TTA mice (Fig. $4 B$, left). APP/TTA mice swam significantly farther from the target zone during probe trials than either control group $\left(F_{(2,51)}=39.86, p<0.001\right)$. Analysis of short-term memory by the more common measure of percentage path in the trained quadrant was consistent with proximity: performance of all genotypes improved with training $\left(F_{(2,102)}=20.70, p<0.001\right)$ but APP/TTA mice learned more slowly than NTG and TTA controls $\left(F_{(2,51)}=13.67, p<0.001\right)$, and by day 3 spent a significantly smaller fraction of their swim path in the correct quadrant than controls (NTG: $p<0.001$; TTA: $p<0.01$ ). Several of the control mice reached criteria performance on day 3 and were removed from further training, therefore comparisons of path length and

proximity were limited to days $1-3$ when all animals could be evaluated. None of the APP/TTA mice (or 11 of 20 controls) had reached criteria performance by this time, and so continued training and testing until they did (Fig. 4D, top). APP/TTA mice required significantly more days of training to reach criteria performance than either TTA or NTG littermates $\left(F_{(2,51)}=16.17, p<0.001\right.$, both $p<$ 0.001; Fig. 4E). As each mouse reached criteria levels, they received one final probe trial $24 \mathrm{~h}$ later to assess long-term memory and then were retired from further training until all of the mice completed training (Fig. 4C). Although APP/TTA mice required more days to reach criteria, once they acquired the task their long-term memory for the platform location was as precise as their NTG and TTA siblings $\left(F_{(2,51)}=1.25\right.$, $p>0.05)$.

Alongside these untreated mice, we examined a replicate cohort of APP/TTA, TTA, and NTG mice that received dox in their drinking water for 2 weeks before testing. During training, the average path length of dox-treated APP/TTA mice was no different from TTA or NTG controls $(p>0.05)$, indicating that transgene suppression restored the performance of APP/TTA mice to that of controls (Fig. $4 A$, right). Additionally, proximity to the trained target during probe trials was similar among genotypes, indicating that dox treatment reversed short-term memory impairment in the APP/TTA mice ( $p>0.05$; Fig. $4 B$, right). Dox-treated APP/TTA mice took the same number of days to reach criteria performance as TTA and NTG controls (both $p>$ 0.05; Fig. $4 D$, bottom; $E$ ). Although transgene suppression brought the performance of APP/TTA mice to the level of similarly treated controls, the effect was not sufficient to distinguish them from untreated APP/TTA mice $(p>0.05)$. Behavioral rescue in this task was thus substantial, but not complete. A final analysis of long-term memory confirmed that all groups recalled the platform location equally well, and were identical to untreated animals (Fig. 4C). These findings indicate that transgene suppression partially reversed impairments in spatial reference learning and short-term memory apparent in untreated APP/ TTA mice of the same age.

\section{Suppression of transgenic APP rescues working memory deficits in RAWM and associative memory impairment in CFC}

Animals next began RAWM training, consisting of eight trials over a single training day. This task allowed us to test working memory errors, which were scored as repeated visits to an incorrect arm. Untreated APP/TTA mice made significantly more errors during RAWM training than either NTG or TTA controls $\left(F_{(2,52)}=5.15, p<0.05\right.$, post hoc, $p<0.01$ and $p<0.05$, respectively; Fig. 5A). Dox treatment completely rescued this working memory deficit. Not only did dox-treated APP/TTA mice make fewer errors than untreated APP/TTA mice $(p<0.01$; Fig. 

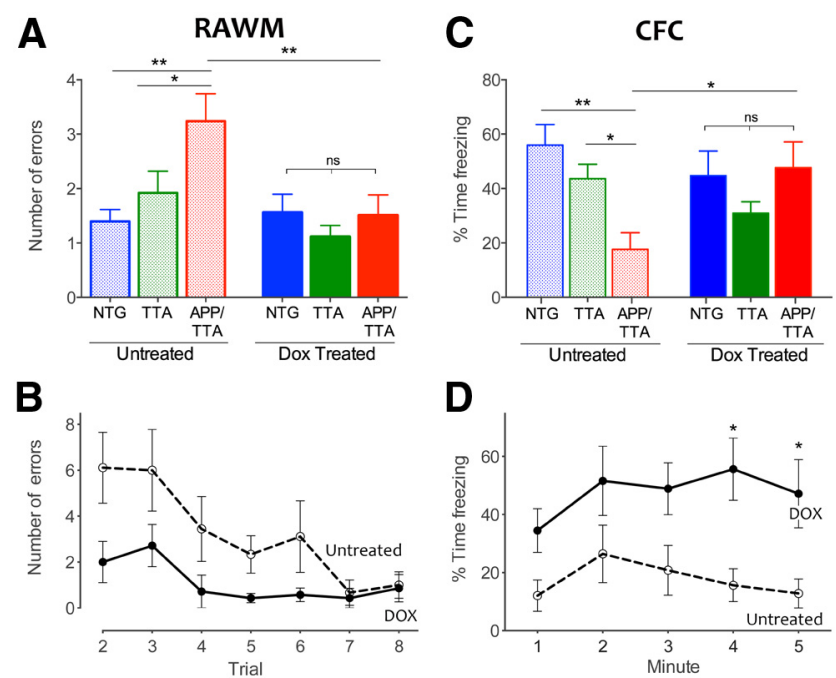

Figure 5. Deficits in working and associative memory are rescued by suppression of transgenic APP/A $\beta$. $A$, The average number of errors made by each genotype over trials $2-8$ of RAWM provides a measure of overall working memory performance. Untreated APP/TTA mice ( $n=10)$ made significantly more repetitive arm entries (errors) than NTG $\left(n=9 ;{ }^{* *} p<0.01\right)$ or TTA controls $\left(n=10 ;{ }^{*} p<0.05\right)$. In contrast, APP/TTA mice treated with dox $(n=9)$ perform this task significantly better than untreated APP/TTA mice $\left({ }^{* *} p<0.01\right)$ and identically to NTG and TTA controls ( $n=10$ dox NTG; $n=9$ dox TTA). $B$, Average RAWM errors plotted by trial for untreated and dox-treated APP/TTA mice. Transgene suppression markedly improved the rate of acquisition in this task. , Untreated APP/TTA mice $(n=10)$ perform significantly worse in CFC than NTG $\left({ }^{* *} p<0.01\right)$ and TTA controls $\left({ }^{*} p<0.05\right)$. Dox treatment rescues this associative memory impairment and returns APP/TTA mice $(n=9)$ to the performance level of control animals. D, Percentage freezing plotted by minute over the 5 min test for untreated and dox-treated APP/TTA mice. Transgene suppression significantly improved associative memory for conditioned fear $\left({ }^{*} p<0.05\right)$.

$5 A, B)$, they performed as well as their dox-treated siblings $\left(F_{(1,52)}\right.$ $=5.68, p<0.05$; post hoc, $p>0.05$ for both NTG and TTA).

Two days after completing RAWM, mice were trained in CFC and tested $24 \mathrm{~h}$ later in the same setting. Baseline freezing before conditioning was similar between genotypes and treatment groups $\left(F_{(2,51)}=0.41, p=0.67\right)$. However, when they were returned to the chamber $1 \mathrm{~d}$ after conditioning, untreated APP/ TTA mice spent significantly less time freezing than NTG and TTA littermates $\left(F_{(2,51)}=3.26, p<0.05\right.$; Fig. $\left.5 C\right)$. In contrast, dox-treated APP/TTA mice showed clear improvement, freezing significantly more than untreated APP/TTA mice $\left(F_{(2,51)}=5.69\right.$, $p<0.01$, post hoc, $p<0.05$; Fig. $5 D)$ and similar to controls $(p>$ 0.05 for both; Fig. $5 C$ ). Transgene suppression thus resulted in complete behavioral rescue of working and associative memory in RAWM and CFC alongside partial rescue of spatial reference learning in MWM.

\section{Suppression of $\mathrm{A} \boldsymbol{\beta}$ accounts for a portion of behavioral recovery}

Because our system regulates $\mathrm{A} \beta$ through the expression of transgenic APP, it is impossible to distinguish whether behavioral recovery following dox treatment was due to diminished $\mathrm{A} \beta$, full-length APP, or other processed derivatives. To address this question, we treated a separate cohort of age-matched APP/TTA and TTA animals with the GSI LY41175. Animals were treated for $5 \mathrm{~d}$ before behavioral analysis with the same test battery used previously for dox-treated animals (Fig. 6A).

Similar to improvements we observed following dox treatment, GSI-treated APP/TTA mice swam the same distance as controls to reach the hidden platform in MWM (Fig. 6B). Both
GSI-treated groups showed similar short-term memory for the trained location during daily probe trials at the end of each training session $\left(F_{(1,16)}=0.99, p>0.05\right.$; Fig. $\left.6 C\right)$. Despite swimming similar distances during training and showing equivalent shortterm memory for the platform location, GSI-treated double transgenic mice took slightly longer to reach criteria performance than TTA controls $(4.78 \pm 0.32 \mathrm{~d}$ vs $3.33 \pm 0.37 \mathrm{~d}, t=2.25, \mathrm{df}=$ $16, p<0.05)$. Nonetheless, the effect of GSI treatment in APP/ TTA mice was nearly identical to that of dox: GSI-treated mice required $4.7 \pm 0.31 \mathrm{~d}$ to reach criterion compared with $4.88 \pm$ $0.48 \mathrm{~d}$ for dox-treated mice, and both values were lower than the $6.0 \pm 0.36 \mathrm{~d}$ required by the untreated APP/TTA group (Fig. 6D). Instead, the main difference between GSI and dox was in the TTA controls, where GSI-treated mice required only $3.3 \mathrm{~d} \pm 0.5 \mathrm{~d}$ to reach criterion compared with $4.0 \pm 0.47 \mathrm{~d}$ for dox. Finally, GSI-treated mice of both genotypes performed equally well on longterm memory testing ( $t$ test, $t=2.29, \mathrm{df}=16, p=0.29$; Fig. $6 E$ ).

We were concerned that the side effects of GSI treatment might confound further testing in RAWM and fear conditioning so we conducted a second open-field test following MWM. While we saw no differences between genotypes for distance $\left(F_{(1,32)}=\right.$ $0.08, p=0.78)$ or center ratio $(t=0.27, \mathrm{df}=16, p=0.80)$, both genotypes were significantly less active during the second open-field test than they had been at the outset of GSI treatment $\left(F_{(1,32)}=8.71\right.$, $p<0.001)$. The decline in spontaneous ambulation was accompanied by hair loss and gastrointestinal changes. Although we continued behavioral testing through RAWM and CFC, the mounting side effects of GSI treatment confounded interpretation of these later tests.

\section{Reduction of membrane-associated A $\boldsymbol{\beta}$ oligomers correlates with cognitive improvement}

Having demonstrated that transgene suppression restored cognitive function at least in part through its effect on $\mathrm{A} \beta$ production, we next examined the possibility that clearance of specific forms of synaptotoxic $\mathrm{A} \beta$ may be an important aspect of this response. Using cortical homogenates from behaviorally tested animals, we measured the relative size and abundance of putative $A \beta$ oligomers in the extracellular-enriched and membrane-associated fractions where these $\mathrm{A} \beta$ assemblies are predominantly detected (Lesné et al., 2006, 2008 Cheng et al., 2007). Two soluble oligomeric $\mathrm{A} \beta$ species, putative hexamers $(\sim 27 \mathrm{kDa})$ and $\mathrm{A} \beta^{\star} 56$, were present at low levels in the extracellular compartment of untreated APP/TTA mice (Fig. 7A). Both oligomers were substantially more concentrated in the membrane-associated extracts, where in addition to hexamers and $\mathrm{A} \beta \beta^{\star} 56$, we also detected $\mathrm{A} \beta$ dimers (Fig. $7 B$ ). Although identification of $A \beta$ trimers was confounded by a nonspecific band at the same molecular weight in the extracellular extract and by APP C-terminal fragments $(\beta$ CTF) in the membrane-enriched fraction, we were able to confirm low levels of apparent $\mathrm{A} \beta$ trimers in the extracellular extracts by 6E10 IP, as reported for other APP transgenic lines ( Lesné et al., 2006; Larson et al., 2012).

All putative soluble oligomeric $\mathrm{A} \beta$ species in both extracellular and membrane-associated extracts were significantly reduced in the dox-treated mice $\left(F_{(1,36)}=194.80, p<0.0001\right.$ for the membrane-associated fraction and $F_{(1,24)}=243.60, p<0.0001$ for extracellular fraction; Fig. $7 A, B)$. The two most prevalent oligomer species, 6 -mer and $\mathrm{A} \beta{ }^{\star} 56$, were reduced by $79 \%$ extracellular $(p<0.0001)$ and $68 \%$ at the membrane $(p<0.0001)$ and by $28 \%$ extracellular $(p<0.05)$ and $55 \%$ at the membrane $(p<$ $0.0001)$, respectively. Although a minor component, $\mathrm{A} \beta$ dimers were reduced by $53 \%$ in the membrane fraction $(p<0.001)$ 


\section{A Experimental design}
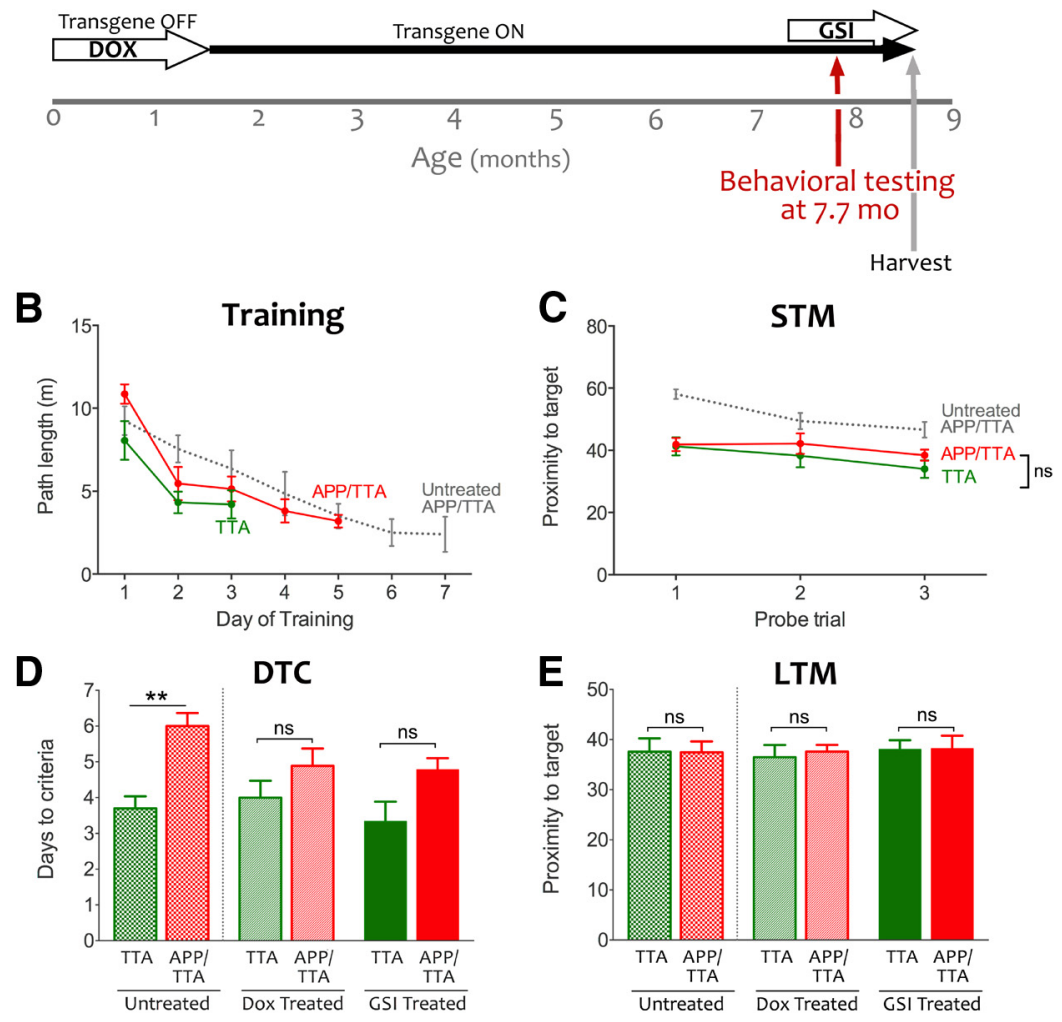

Figure 6. Selective reduction of $A \beta$ with GSI largely phenocopies transgene suppression with dox. $A$, As in our earlier experiments, dox was used to delay transgene expression until adulthood. Transgenic APP expression was initiated at 6 weeks of age by removing dox from the diet, and remained active for the duration of the experiment. Therapeutic intervention to prevent $A \beta$ release with GSI began at 7.5 months of age, and behavioral testing was started $5 \mathrm{~d}$ later. $\boldsymbol{B}$, Average path length during MWM training for GSI-treated APP/TTA (red) and TTA mice (green). Performance of untreated APP/TTA animals is shown for comparison (gray; reproduced from Fig. 3). GSI-treated APP/TTA mice required fewer training days than untreated APP/TTA mice, but more than GSI-treated TTA controls ( $n=9$ for each genotype). C, GSI treatment improved short-term memory (STM) of APP/TTA mice during daily probe trials to the level of TTA controls. $D$, Untreated APP/TTA mice required significantly more days of training to reach criteria performance than TTA controls $\left({ }^{* *} p<0.01\right)$; however, this impairment was attenuated by both dox and GSI treatment. Data for this graph was analyzed by two-way ANOVA to allow comparison between treatment groups $\left(F_{(1,50)}=19.70, p<\right.$ $0.0001)$; analyses presented in the text were limited to GSI-treated groups and therefore used $t$ test. $E$, All groups, regardless of genotype or treatment, performed identically during the long-term probe trial conducted $24 \mathrm{~h}$ after the final training session. Untreated and dox-treated days to criteria and long-term memory (LTM) values are reproduced from Figure 4.

while the largest aggregates, protofibrils, were decreased by $42 \%$ $(p<0.0001)$.

Because 6E10 detects many processed fragments of APP in addition to oligomeric $\mathrm{A} \beta$, we performed nondenaturing analyses using the A11 antibody, which detects soluble nonamyloid oligomers larger than $\sim 20 \mathrm{kDa}$ (Kayed et al., 2003; Lesné et al., 2006). Under these conditions, dot blots probed with A11 confirmed the presence of substantial oligomeric $\mathrm{A} \beta$ in both extracellular and membrane extracts from untreated APP/TTA animals. Following transgene suppression, the A11 signal was reduced by $62 \%$ in the extracellular fraction (main effect of treatment $F_{(1,12)}=191.7, p<0.0001$; post hoc, $\left.p<0.0001\right)$ and by $68 \%$ in the membrane fraction $(p<0.01$; Fig. $7 D)$. The dot blots were also coincubated with $6 \mathrm{E} 10$, which showed a quantitatively larger decrease in signal intensity following dox treatment than in A11 (extracellular, 81\%; membrane, $71 \%$ ), consistent with its ability to detect multiple APP fragments, A11-positive and A11negative $\mathrm{A} \beta$ oligomers, and monomeric $\mathrm{A} \beta$. These findings indicate that soluble oligomeric $\mathrm{A} \beta$ species were selectively reduced upon genetic suppression of transgenic APP while the burden of insoluble amyloid remained unchanged. Moreover, the extent this reduction parallels the decrease in ISF A $\beta$ levels observed by microdialysis before and after transgene suppression.

\section{Synaptic recovery despite sustained amyloid}

Past work has shown that exposure to oligomeric $A \beta$ is rapidly synaptotoxic in vitro, which led us to test whether synaptic markers were also reduced in untreated APP/TTA mice as they are in several other amyloid-bearing AD models (Calon et al., 2004; Almeida et al., 2005; Zhao et al., 2006; D’Amelio et al., 2011). Moreover, we wanted to determine whether synaptic recovery accompanied the decrease in oligomeric $\mathrm{A} \beta$ with transgene suppression, which might support their behavioral improvement. We quantified the levels of both postsynaptic PSD95 and presynaptic synapsin Ia/b in cortical extracts from behaviorally tested mice (Fig. $8 A-C$ ). Western blotting confirmed that untreated APP/TTA mice have less PSD95 than TTA controls $\left(F_{(1,28)}=25.80, p<0.01\right.$; Fig. $8 B)$ as well as lower levels of synapsin $\left(F_{(1,27)}=6.20, p=0.05\right.$; Fig. $\left.8 C\right)$. Dox treatment to suppress transgenic APP increased the amount of both proteins in APP/TTA mice, but did not affect their levels in TTA controls $\left(F_{(1,28)}=11.80\right.$, $p=0.002$ for PSD95 and $F_{(1,27)}=3.70$, $p=0.04$ for synapsin).

While these changes in synapsin and PSD95 are consistent with synapse loss throughout the cortex of untreated APP/ TTA mice, past work has shown that the greatest decrease in synapse density occurs in the immediate vicinity of amyloid plaques (Spires et al., 2005; Dong et al., 2007; Spires-Jones et al., 2007; Knafo et al., 2009; Koffie et al., 2009). Knowing that dox-treated mice showed behavioral improvements despite the persistence of amyloid plaques, we tested whether plaque-associated synapse loss was rescued by lowering $\mathrm{A} \beta$ production. We manually selected thioflavine-positive plaques from the rostral forebrain ranging in size from $2500-11,000 \mu \mathrm{m}^{2}$ so that the distribution of plaque sizes was no different between dox-treated and untreated mice (unpaired Student's $t$ test, $p>0.05$ ). We then measured the area of synaptophysin immunostaining in a $0.036 \mathrm{~mm}^{2}$ region surrounding each plaque (one field of view at $40 \times$ magnification) to compare the density of synapses in untreated and doxtreated APP/TTA mice (Fig. 8D). The area of synaptophysin staining in the vicinity of fibrillar deposits was markedly higher in the dox-treated animals than in their untreated siblings $(t=3.34$, $p<0.01$; Fig. $8 E)$. This suggests that synaptic loss is reversible, as were cognitive deficits, once APP and $A \beta$ are reduced.

We formally tested the relationship between synaptic protein expression and the concentration of oligomeric $\mathrm{A} \beta$ measured in individual APP/TTA mice with or without dox treatment. We focused on the two most prevalent oligomeric $\mathrm{A} \beta$ species, $\mathrm{A} \beta{ }^{\star} 56$ 

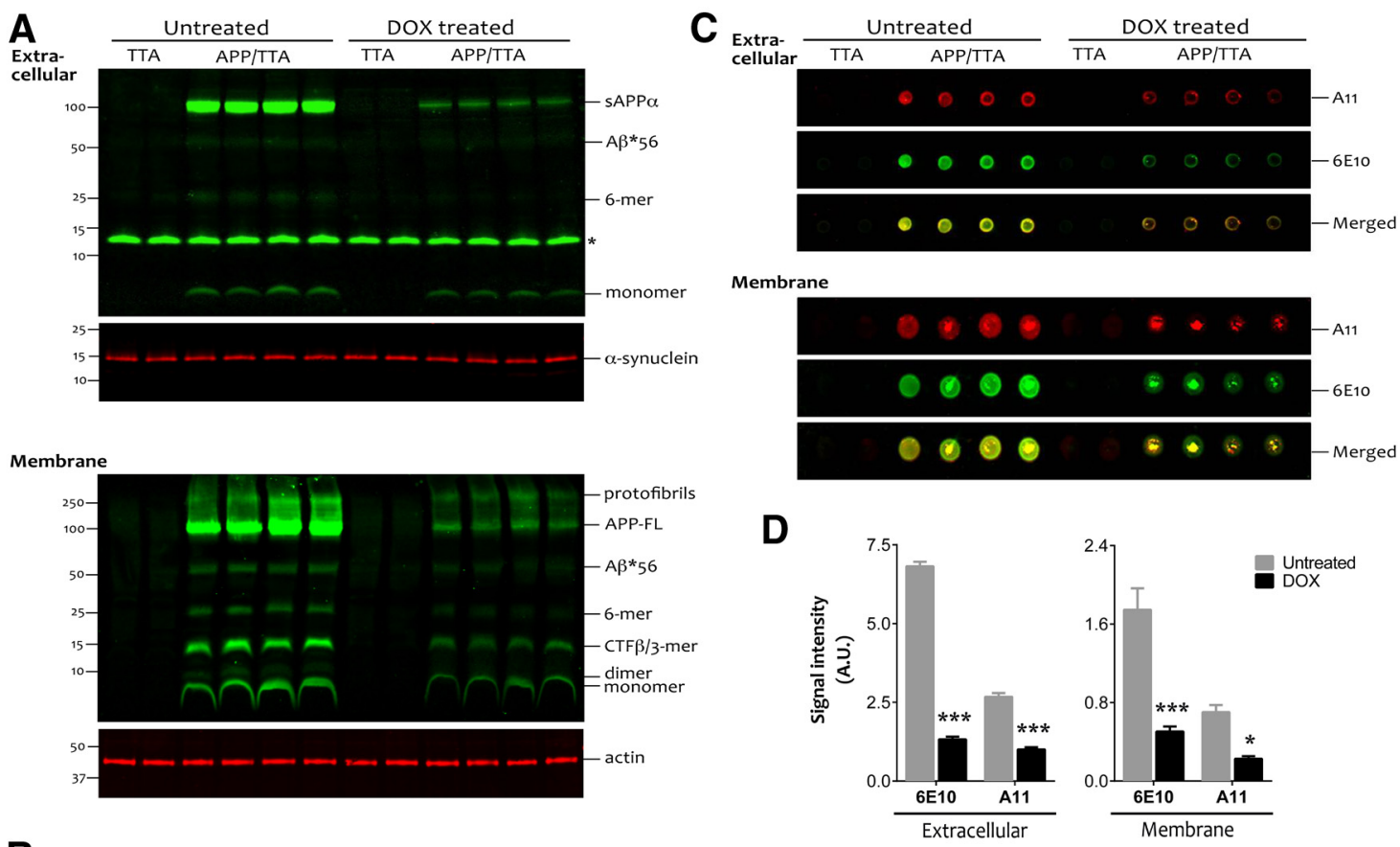

B

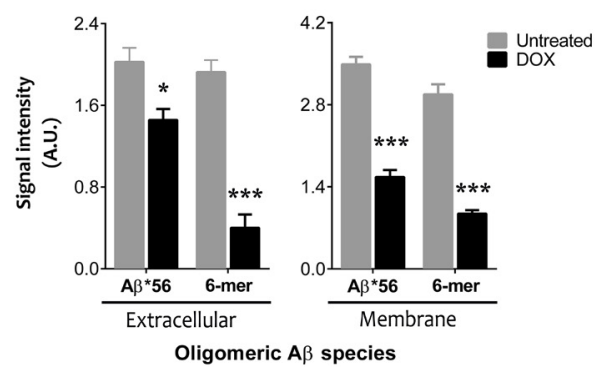

Oligomeric A $\beta$ species

Figure 7. APP suppression reduces soluble synaptotoxic $A \beta$ assemblies. $A$, A four-step biochemical fractionation was used to enrich for extracellular (top) and membrane-associated proteins (bottom) in cortical samples from behaviorally tested mice ( $n=4$ APP/TTA untreated, $n=4$ APP/TTA dox; $n=2$ TTA untreated, $n=2$ TTA dox). Immunoblotting with anti-A $\beta$ antibody 6 E10 revealed multiple oligomeric $A \beta$ species in addition to full-length APP and SAPP $\alpha$. Putative hexamers (6-mers) and $A \beta^{*} 56$ were especially prevalent in the membrane-associated fraction. The asterisk in the upper blot indicates a band of nonspecific binding present in all samples. Additional gels were prepared with an identical volume of the same samples and probed for $\alpha$-synuclein (extracellular) or actin (membrane) to demonstrate equal loading across lanes ( $p>0.05$ between treatment conditions for both fractions). $\boldsymbol{B}$, Densitometry analysis revealed that both $A \beta^{*} 56$ and hexamers were significantly diminished in dox-treated APP/TTA animals compared with untreated controls. C, Dot blots were used to distinguish the signal due to oligomeric $A \beta$ from that caused by other fragments of APP ( $n=4$ APP/TTA untreated, $n=4$ APP/TTA dox; $n=2$ TTA untreated, $n=2$ TTA dox). Blots were coincubated with oligomer-specific A11 and with 6E10, and detected with anti-rabbit IR680 and anti-mouse IR800 secondaries, respectively. D, Signal intensity for both A11 and 6E10 was decreased after transgene suppression compared with untreated controls; ${ }^{*} p<$ $0.05,{ }^{* * *} p<0.001$. A.U., arbitrary units.

and hexamers, measured by Western blot of extracellular and membrane extracts (Fig. 7A), as well as A11-positive oligomers measured by dot blot (Fig. 7C). Levels of these oligomers were tested for correlation against expression of the presynaptic marker synapsin measured by Western blot of intracellular extract from the same animals (Fig. 8A). Based on the general trend for each of these proteins before and after transgene suppression, we predicted there would be a strong negative correlation between oligomeric $\mathrm{A} \beta$ concentration and synaptic protein expression. Linear regression analyses confirmed this prediction, revealing $R^{2}$ of 0.81 (extracellular) and 0.76 (membrane) for hexamers ( $p<0.01$ for both; Fig. $9 A$ ), $R^{2}$ of 0.59 (extracellular) and 0.73 (membrane) for $\mathrm{A} \beta^{\star 56}(p<0.05$ and $p<0.01$, respectively; Fig. $9 B$ ), and $R^{2}$ of 0.69 (extracellular) and 0.68 (membrane) for A11-positive oligomers ( $p<0.05$ for both; Fig. $9 C$ ). Our data thus supports and extends past in vitro studies suggesting a direct relationship between soluble oligomeric $\mathrm{A} \beta$ and synaptic integrity.
Synaptic regrowth corresponds with restored cofilin activity While oligomeric $A \beta$ may initiate synaptic collapse, the intracellular mediator of structural changes at the synapse is the actin cytoskeleton. Opposing actions of Rho- and Rac-GTPases are critical to the balance between synapse maintenance and turnover, and imbalance of these pathways is associated with several neurodegenerative conditions (Antoine-Bertrand et al., 2011; Ma et al., 2012). Both pathways ultimately converge on the actinbinding protein cofilin, which promotes collapse through actin depolymerization, but only in its active, dephosphorylated form. Past work has implicated the Rac-GTPase pathway in amyloidassociated synaptic deficits, showing that exposure to oligomeric $\mathrm{A} \beta$ diminishes activity of its downstream effector PAK in primary neurons, and conversely that oligomer-induced loss of synaptic markers can be ameliorated by increasing PAK levels (Zhao et al., 2006).

Western blotting of cortical intracellular homogenates revealed a significant imbalance of cofilin phosphorylation in un- 
A

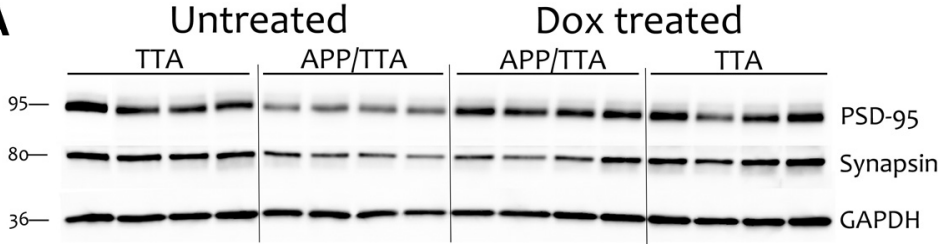

B
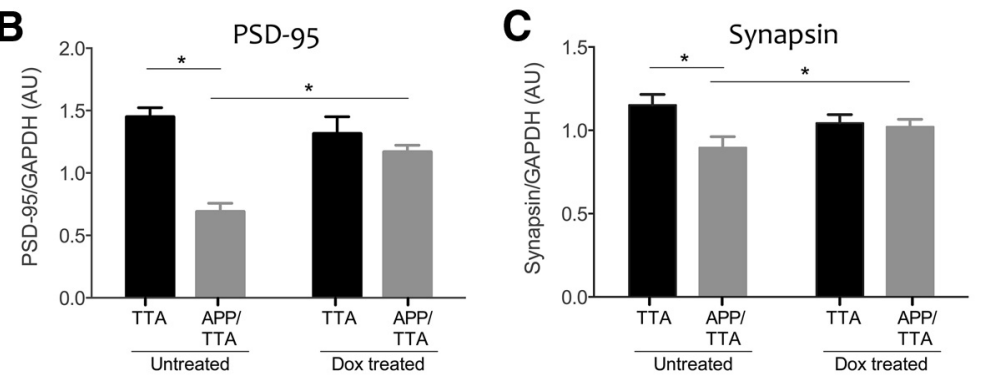

D

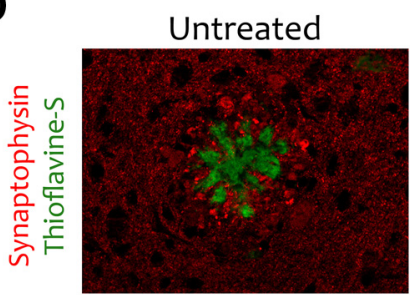

Figure 8. Synaptic protein levels and synaptic area are restored by suppression of transgenic APP/A $\beta . A$, Immunoblotting was used to measure the levels of presynaptic and postsynaptic proteins synapsin and PSD95 in cortical homogenates from behaviorally tested animals. $B, C$, The signal intensity revealed significant deficits in both synapsin and PSD95 between untreated APP/TTA mice $(n=8)$ and TTA controls $\left(n=8 ;{ }^{*} p<0.05\right)$. Levels of both proteins were increased by dox treatment in APP/TTA mice $(n=8$; $\left.{ }^{*} p<0.05\right)$ to levels that were indistinguishable from TTA controls $(n=8)$. $\boldsymbol{D}$, Synaptophysin immunostaining (red) was used to estimate the area occupied by synaptic terminals in the vicinity of thioflavine-positive fibrillar plaques (green) at the conclusion of behavioral testing. $\boldsymbol{E}$, Consistent with the recovery of synaptic proteins, the area of synaptophysin immunostaining was significantly greater in dox-treated APP/TTA mice than in untreated controls ( ${ }^{* *} p<0.01 ; n=8$ untreated; $n=10$ dox).
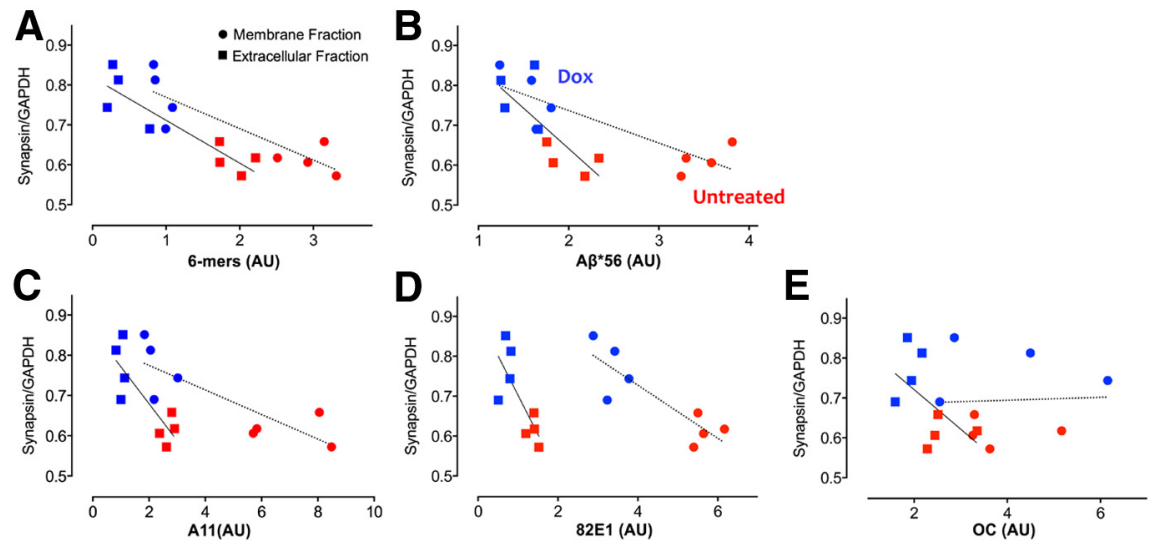

Figure 9. Synaptic protein expression correlates with oligomeric $A \beta$ levels. $A, B$, Graphs showing the level of synapsin protein measured by Western blot of intracellular tissue extract as a function of the amount of $A \beta^{*} 56(\boldsymbol{A}) A \beta$ hexamer $(\boldsymbol{B})$ measured by Western blot of extracellular (squares) or membrane extract (circles) from the same animal. $\boldsymbol{C}-\boldsymbol{E}$, Graph showing synapsin expression as a function of A11-positive $(\boldsymbol{C})$ and 82E1-positive $(\boldsymbol{D})$ oligomeric $A \beta$ or $0 C$-positive fibrils $(\boldsymbol{E})$ measured by dot blot. Values are expressed as arbitrary units (AU). Red, $n=4$ untreated; blue, $n=4$ dox.

treated APP/TTA mice, which harbored more protein in the inactive phosphorylated state than controls $\left(F_{(1,12)}=8.87, p=\right.$ 0.01 , post hoc, $p<0.05$; Fig. $10 A)$. Cofilin phosphorylation was restored to normal by transgene suppression (post hoc, $p>0.05$ ) without affecting the total amount of cofilin protein (Fig. 10B). Our results suggest that aberrant cofilin activation may mediate

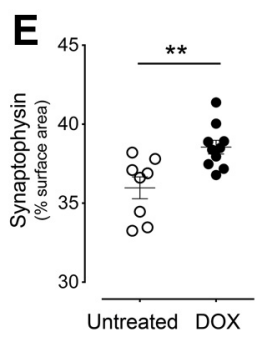

Untreated DOX synaptic loss in our model through a dynamic process that returns to normal once APP/A $\beta$ subsides. Consistent with past work (Zhao et al., 2006; Ma et al., 2008), we observed a significant decrease of Thr423 phosphorylation of PAK1 in double transgenic mice $\left(F_{(1,12)}=96.23, p<\right.$ 0.0001 ; Fig. $10 C, D)$. However, pPAK1 levels were not further altered by transgene suppression. These findings suggest that the recovery of cofilin activity after transgene suppression, as well as the rescue of synaptic proteins and cognitive behavior, are all independent of PAK1 activity.

\section{Discussion}

One of the uncertainties surrounding new anti-amyloid treatments for $\mathrm{AD}$ is whether lowering the concentration of soluble $A \beta$ will be sufficient to achieve substantial and sustained cognitive improvement. Here, we set out to test the extent of behavioral and synaptic recovery that could be achieved by reducing soluble $\mathrm{A} \beta$ without macroscopically altering insoluble plaque burden. We describe substantial cognitive deficits while transgene expression persists, but nearly complete behavioral recovery across a wide range of memory tasks following acute reduction of APP and A $\beta$. Cognitive improvements correlated with restoration of synaptic proteins, increased synaptic density surrounding amyloid plaques, and normalized phosphorylation of actin-binding proteins controlling synaptic stability. Together, these findings argue that high levels of APP and the ensuing supply of soluble $A \beta$ actively dampen synaptic condition and cognitive function, but indicate a striking potential for structural and functional recovery once further production of APP and A $\beta$ are controlled. Remarkably, this recovery occurred despite the continued presence of deposited amyloid and associated pathology, suggesting the possibility for considerable therapeutic benefit by targeting full-length APP and/or soluble $\mathrm{A} \beta$ to arrest plaque growth without the need to reduce plaque burden.

To determine whether the cognitive improvements observed following transgene suppression were mediated by the reduction in $A \beta$, we used chronic GSI treatment to prevent $A \beta$ release while the animals continued to overproduce APP. We found that GSI improved the performance of APP/TTA mice in the MWM, but did not offer complete rescue. This outcome suggests that either our GSI did not lower $A \beta$ enough for full recovery, or that $A \beta$ is only partly responsible for cognitive decline in our mice. Importantly, these behavioral improvements following GSI treatment appear in 
sharp contrast to our recent finding that GSI had little effect on other phenotypes such as electroencephalographic sharpwave discharge that could be attenuated by APP suppression (Born et al., 2014). Thus, $\mathrm{A} \beta$ does not contribute to every phenotype observed in APP models, but does appear to play a role in their cognitive dysfunction. Our results join a handful of past studies to separate the effects of APP from $\mathrm{A} \beta$ using passive immunization, $\beta$-secretase and $\gamma$-secretase inhibitors, or $\gamma$-secretase modulators. Although they differ in extent of cognitive recovery, starting plaque load, and testing procedures, these studies collectively point to soluble $A \beta$ as an important mediator of cognitive decline in APP transgenic models (Dodart et al., 2002; Comery et al., 2005; Lee et al., 2006; Martone et al., 2009; Fukumoto et al., 2010; Balducci et al., 2011; Chang et al., 2011; Mitani et al., 2012, 2013; Rogers et al., 2012).

Cognitive improvements observed after transgene suppression were associated with structural recovery at the synaptic level. A limited number of studies in vitro and in vivo have hinted at the possibility of synaptic recovery following treatments to reduce $\mathrm{A} \beta$ levels, but never in the context of sustained amyloid load (Buttini et al., 2005; Rozkalne et al., 2009; Spires-Jones et al., 2009; Wei et al., 2010). Consistent with past work showing diminished levels of PSD95 in cultured neurons from Tg2576 mice (Almeida et al., 2005), we observed loss of both the presynaptic and postsynaptic markers in untreated APP/ TTA mice. However, this deficit was fully reversible following short-term suppression of transgenic APP. As in other APP transgenic models, we observed diminished synaptic staining surrounding amyloid plaques in untreated APP/TTA mice (Dong et al., 2007; Koffie et al., 2009; Spires-Jones and Knafo, 2012), but demonstrate significant structural recovery following APP/A $\beta$ suppression. Although the thioflavine-positive plaque load remained stable, the concentration of potentially synaptotoxic oligomeric $A \beta$ decreased significantly after APP suppression. The amount of oligomeric $A \beta$ in the brain was inversely correlated with synaptic protein levels and synaptic density. Both markers of synaptic integrity increased significantly when oligomeric $\mathrm{A} \beta$ decreased.

Previous work with cultured neurons has suggested a mechanistic link between exposure to oligomeric $\mathrm{A} \beta$ and the intracellular signaling pathways that regulate synapse stability. Work has revealed roles for the PAKs and their downstream target cofilin in spine loss following application of soluble $\mathrm{A} \beta$ aggregates (Zhao et al., 2006; Shankar et al., 2007; Davis et al., 2011; MendozaNaranjo et al., 2012). The activity of both proteins is regulated by phosphorylation, which in the case of cofilin, serves as a way to stabilize synaptic structure by preventing F-actin disassembly (Mizuno, 2013). We find that cofilin phosphorylation was substantially elevated in the cortex of untreated APP/TTA mice, where it may either be a direct result of exposure to soluble forms of $\mathrm{A} \beta$ or may serve as a compensatory response to protect against further synapse loss. Consistent with the former idea, cofilin phosphorylation was shown to increase rapidly in primary neurons following application of aggregated $\mathrm{A} \beta$ (Heredia et al., 2006). Supporting the latter idea, constitutively inactive cofilin (S3D) protects neurons from spine loss during prolonged exposure to oligomeric A $\beta$ (Shankar et al., 2007). Regardless of whether the response is direct or reactive, cofilin phosphorylation comes at the cost of structural plasticity required for learningassociated changes in synaptic structure and function. Cofilin phosphorylation is dynamically regulated by neuronal stimulation in vitro and behavioral learning in vivo, where it participates both in modulating synaptic size and in trafficking AMPA receptors to the membrane (Saneyoshi and Hayashi, 2012). Loss of cofilin in the forebrain impairs associative memory, while blocking its activation retards extinction learning (Rust et al., 2010; Wang et al., 2013). Thus, diminished cofilin activity in untreated APP/TTA mice may contribute to their poor cognitive flexibility.

Once the production of transgenic APP and $A \beta$ was suppressed, cofilin activity returned to normal and synapse density around plaques increased. Past work identified p21-associated kinase, PAK1, as a key mediator of oligomeric $\mathrm{A} \beta$-induced synapse loss (Zhao et al., 2006). As shown for the Tg2576 model, we too observed a dramatic reduction of PAK1 phosphorylation in untreated APP/TTA mice. In contrast to the complete rescue of PAK1 activity found by Zhao et al. (2006) following anti-A $\beta$ antibody treatment, we found no further change in PAK1 phosphorylation with APP/A $\beta$ suppression. Although we have not excluded the possibility for cellular redistribution of PAK1 following APP suppression (Ma et al., 2008), our findings suggest that synapse recovery and cognitive improvement in our model are independent of PAK1 signaling.

While past work linking oligomeric $\mathrm{A} \beta$ to synapse loss provided a framework for interpreting our data, we cannot exclude the possibility that other fragments of APP may also contribute to 
synapse loss and cognitive decline in the APP/TTA mice. Genetically inhibiting the expression of full-length APP not only lowered $\mathrm{A} \beta$ production but also reduced APP, soluble extracellular derivatives (sAPP), and APP intracellular domain. Our system thereby provides experimental proof of principle that modulating APP gene expression in the human brain might be therapeutically beneficial. Based on these results, we propose that antisense oligodeoxynucleotides (ASO) targeting APP mRNA could offer a means of lowering $A \beta$ without assuming it is the sole causal agent. ASO therapy has the added advantage of being directly translatable to clinical trials, and is currently in testing for both spinal muscular atrophy and amyotrophic lateral sclerosis (www.Clinicaltrials.gov ID NCT01839656; Miller et al., 2013). Although considerable effort has focused on selectively lowering $A \beta$, our study shows that targeting full-length APP may offer another means of accomplishing this goal.

Collectively, our results point to transient assemblies of $A \beta$ as the most likely cause of synaptic and cognitive deficits in our APP/TTA mice. We demonstrate substantial structural and functional improvements following short-term suppression of transgenic APP and the subsequent reduction of monomeric and oligomeric $A \beta$, despite the continued presence of fibrillar amyloid deposits. We further show that aberrant cofilin phosphorylation corresponds with synaptic loss in untreated APP/TTA mice, and that cofilin activity and synaptic integrity are restored to normal following arrest of transgenic APP and A $\beta$. Future studies will need to address whether this benefit can be maintained long term, and if the same degree of recovery observed here can be achieved at later stages of disease when amyloid load increases exponentially (Kawarabayashi et al., 2001; Rodgers et al., 2012) and cognitive impairment becomes progressively worse (Westerman et al., 2002; Trinchese et al., 2004). Nonetheless, at least at this early stage of disease, our findings support the possibility for considerable functional and structural recovery by genetically targeting transient forms of soluble $\mathrm{A} \beta$.

\section{References}

Almeida CG, Tampellini D, Takahashi RH, Greengard P, Lin MT, Snyder EM, Gouras GK (2005) $\beta$-amyloid accumulation in APP mutant neurons reduces PSD-95 and GluR1 in synapses. Neurobiol Dis 20:187-198. CrossRef Medline

Antoine-Bertrand J, Villemure JF, Lamarche-Vane N (2011) Implication of rho GTPases in neurodegenerative diseases. Curr Drug Targets 12:12021215. CrossRef Medline

Balducci C, Mehdawy B, Mare L, Giuliani A, Lorenzini L, Sivilia S, Giardino L, Calzà L, Lanzillotta A, Sarnico I, Pizzi M, Usiello A, Viscomi AR, Ottonello S, Villetti G, Imbimbo BP, Nisticò G, Forloni G, Nisticò R (2011) The $\gamma$-secretase modulator CHF5074 restores memory and hippocampal synaptic plasticity in plaque-free Tg2576 mice. J Alzheimers Dis 24:799816. CrossRef Medline

Born HA, Kim JY, Savjani RR, Das P, Dabaghian YA, Guo Q, Yoo JW, Schuler DR, Cirrito JR, Zheng H, Golde TE, Noebels JL, Jankowsky JL (2014) Genetic suppression of transgenic APP rescues hypersynchronous network activity in a mouse model of Alzheimer's disease. J Neurosci 34: 3826-3840. CrossRef Medline

Busche MA, Eichhoff G, Adelsberger H, Abramowski D, Wiederhold KH, Haass C, Staufenbiel M, Konnerth A, Garaschuk O (2008) Clusters of hyperactive neurons near amyloid plaques in a mouse model of Alzheimer's disease. Science 321:1686-1689. CrossRef Medline

Buttini M, Masliah E, Barbour R, Grajeda H, Motter R, Johnson-Wood K, Khan K, Seubert P, Freedman S, Schenk D, Games D (2005) $\beta$-amyloid immunotherapy prevents synaptic degeneration in a mouse model of Alzheimer's disease. J Neurosci 25:9096-9101. CrossRef Medline

Calon F, Lim GP, Yang F, Morihara T, Teter B, Ubeda O, Rostaing P, Triller A, Salem N Jr, Ashe KH, Frautschy SA, Cole GM (2004) Docosahexaenoic acid protects from dendritic pathology in an Alzheimer's disease mouse model. Neuron 43:633-645. CrossRef Medline
Chang WP, Huang X, Downs D, Cirrito JR, Koelsch G, Holtzman DM, Ghosh AK, Tang J (2011) $\beta$-secretase inhibitor GRL-8234 rescues age-related cognitive decline in APP transgenic mice. FASEB J 25:775-784. CrossRef Medline

Cheng IH, Scearce-Levie K, Legleiter J, Palop JJ, Gerstein H, Bien-Ly N, Puoliväli J, Lesné S, Ashe KH, Muchowski PJ, Mucke L (2007) Accelerating amyloid- $\beta$ fibrillization reduces oligomer levels and functional deficits in Alzheimer disease mouse models. J Biol Chem 282:23818-23828. CrossRef Medline

Cirrito JR, May PC, O’Dell MA, Taylor JW, Parsadanian M, Cramer JW, Audia JE, Nissen JS, Bales KR, Paul SM, DeMattos RB, Holtzman DM (2003) In vivo assessment of brain interstitial fluid with microdialysis reveals plaque-associated changes in amyloid- $\beta$ metabolism and half-life. J Neurosci 23:8844-8853. Medline

Cirrito JR, Disabato BM, Restivo JL, Verges DK, Goebel WD, Sathyan A, Hayreh D, D'Angelo G, Benzinger T, Yoon H, Kim J, Morris JC, Mintun MA, Sheline YI (2011) Serotonin signaling is associated with lower amyloid- $\beta$ levels and plaques in transgenic mice and humans. Proc Natl Acad Sci U S A 108:14968-14973. CrossRef Medline

Comery TA, Martone RL, Aschmies S, Atchison KP, Diamantidis G, Gong X, Zhou H, Kreft AF, Pangalos MN, Sonnenberg-Reines J, Jacobsen JS, Marquis KL (2005) Acute $\gamma$-secretase inhibition improves contextual fear conditioning in the Tg2576 mouse model of Alzheimer's disease. J Neurosci 25:8898-8902. CrossRef Medline

D’Amelio M, Cavallucci V, Middei S, Marchetti C, Pacioni S, Ferri A, Diamantini A, De Zio D, Carrara P, Battistini L, Moreno S, Bacci A, Ammassari-Teule M, Marie H, Cecconi F (2011) Caspase-3 triggers early synaptic dysfunction in a mouse model of Alzheimer's disease. Nat Neurosci 14:69-76. CrossRef Medline

D’Amore JD, Kajdasz ST, McLellan ME, Bacskai BJ, Stern EA, Hyman BT (2003) In vivo multiphoton imaging of a transgenic mouse model of Alzheimer disease reveals marked thioflavine-S-associated alterations in neurite trajectories. J Neuropathol Exp Neurol 62:137-145. Medline

Davis RC, Marsden IT, Maloney MT, Minamide LS, Podlisny M, Selkoe DJ, Bamburg JR (2011) Amyloid $\beta$ dimers/trimers potently induce cofilinactin rods that are inhibited by maintaining cofilin-phosphorylation. Mol Neurodegener 6:10. CrossRef Medline

Dodart JC, Bales KR, Gannon KS, Greene SJ, DeMattos RB, Mathis C, DeLong CA, Wu S, Wu X, Holtzman DM, Paul SM (2002) Immunization reverses memory deficits without reducing brain $\mathrm{A} \beta$ burden in Alzheimer's disease model. Nat Neurosci 5:452-457. Medline

Dong H, Martin MV, Chambers S, Csernansky JG (2007) Spatial relationship between synapse loss and $\beta$-amyloid deposition in $\operatorname{Tg} 2576$ mice. J Comp Neurol 500:311-321. CrossRef Medline

Fukumoto H, Takahashi H, Tarui N, Matsui J, Tomita T, Hirode M, Sagayama M, Maeda R, Kawamoto M, Hirai K, Terauchi J, Sakura Y, Kakihana M, Kato K, Iwatsubo T, Miyamoto M (2010) A noncompetitive BACE1 inhibitor TAK-070 ameliorates A $\beta$ pathology and behavioral deficits in a mouse model of Alzheimer's disease. J Neurosci 30:11157-11166. CrossRef Medline

Hartman RE, Izumi Y, Bales KR, Paul SM, Wozniak DF, Holtzman DM (2005) Treatment with an amyloid- $\beta$ antibody ameliorates plaque load, learning deficits, and hippocampal long-term potentiation in a mouse model of Alzheimer's disease. J Neurosci 25:6213-6220. CrossRef Medline

Heredia L, Helguera P, de Olmos S, Kedikian G, Solá Vigo F, LaFerla F, Staufenbiel M, de Olmos J, Busciglio J, Cáceres A, Lorenzo A (2006) Phosphorylation of actin-depolymerizing factor/cofilin by LIM-kinase mediates amyloid $\beta$-induced degeneration: a potential mechanism of neuronal dystrophy in Alzheimer's disease. J Neurosci 26:6533-6542. CrossRef Medline

Hong S, Quintero-Monzon O, Ostaszewski BL, Podlisny DR, Cavanaugh WT, Yang T, Holtzman DM, Cirrito JR, Selkoe DJ (2011) Dynamic analysis of amyloid $\beta$-protein in behaving mice reveals opposing changes in ISF versus parenchymal $\mathrm{A} \beta \mathrm{a}$ during age-related plaque formation. J Neurosci 31:15861-15869. CrossRef Medline

Jankowsky JL, Slunt HH, Gonzales V, Savonenko AV, Wen JC, Jenkins NA, Copeland NG, Younkin LH, Lester HA, Younkin SG, Borchelt DR (2005) Persistent amyloidosis following suppression of $A \beta$ production in a transgenic model of Alzheimer's disease. PLoS Med 2:e355. CrossRef Medline Janus C, Pearson J, McLaurin J, Mathews PM, Jiang Y, Schmidt SD, Chishti MA, Horne P, Heslin D, French J, Mount HT, Nixon RA, Mercken M, 
Bergeron C, Fraser PE, St George-Hyslop P, Westaway D (2000) A $\beta$ peptide immunization reduces behavioural impairment and plaques in a model of Alzheimer's disease. Nature 408:979-982. CrossRef Medline

Kawarabayashi T, Younkin LH, Saido TC, Shoji M, Ashe KH, Younkin SG (2001) Age-dependent changes in brain, CSF, and plasma amyloid $\beta$ protein in the Tg2576 transgenic mouse model of Alzheimer's disease. J Neurosci 21:372-381. Medline

Kayed R, Head E, Thompson JL, McIntire TM, Milton SC, Cotman CW, Glabe CG (2003) Common structure of soluble amyloid oligomers implies common mechanism of pathogenesis. Science 300:486-489. CrossRef Medline

Knafo S, Alonso-Nanclares L, Gonzalez-Soriano J, Merino-Serrais P, Fernaud-Espinosa I, Ferrer I, DeFelipe J (2009) Widespread changes in dendritic spines in a model of Alzheimer's disease. Cereb Cortex 19:586592. CrossRef Medline

Koffie RM, Meyer-Luehmann M, Hashimoto T, Adams KW, Mielke ML, Garcia-Alloza M, Micheva KD, Smith SJ, Kim ML, Lee VM, Hyman BT, Spires-Jones TL (2009) Oligomeric amyloid $\beta$ associates with postsynaptic densities and correlates with excitatory synapse loss near senile plaques. Proc Natl Acad Sci U S A 106:4012-4017. CrossRef Medline

Kotilinek LA, Bacskai B, Westerman M, Kawarabayashi T, Younkin L, Hyman BT, Younkin S, Ashe KH (2002) Reversible memory loss in a mouse transgenic model of Alzheimer's disease. J Neurosci 22:6331-6335. Medline

Kuchibhotla KV, Goldman ST, Lattarulo CR, Wu HY, Hyman BT, Bacskai BJ (2008) $\mathrm{A} \beta$ plaques lead to aberrant regulation of calcium homeostasis in vivo resulting in structural and functional disruption of neuronal networks. Neuron 59:214-225. CrossRef Medline

Kuchibhotla KV, Lattarulo CR, Hyman BT, Bacskai BJ (2009) Synchronous hyperactivity and intercellular calcium waves in astrocytes in Alzheimer mice. Science 323:1211-1215. CrossRef Medline

Larson ME, Lesne SE (2012) Soluble A $\beta$ oligomer production and toxicity. J Neurochem 120 [Suppl 1]:125-139. CrossRef Medline

Larson M, Sherman MA, Amar F, Nuvolone M, Schneider JA, Bennett DA, Aguzzi A, Lesné SE (2012) The complex PrP(c)-Fyn couples human oligomeric $A \beta$ with pathological tau changes in Alzheimer's disease. J Neurosci 32:16857-16871a. CrossRef Medline

Le R, Cruz L, Urbanc B, Knowles RB, Hsiao-Ashe K, Duff K, Irizarry MC, Stanley HE, Hyman BT (2001) Plaque-induced abnormalities in neurite geometry in transgenic models of Alzheimer disease: implications for neural system disruption. J Neuropathol Exp Neurol 60:753-758. Medline

Lee EB, Leng LZ, Zhang B, Kwong L, Trojanowski JQ, Abel T, Lee VM (2006) Targeting amyloid- $\beta$ peptide $(\mathrm{A} \beta)$ oligomers by passive immunization with a conformation-selective monoclonal antibody improves learning and memory in $\mathrm{A} \beta$ precursor protein (APP) transgenic mice. J Biol Chem 281:4292-4299. CrossRef Medline

Lesné S, Koh MT, Kotilinek L, Kayed R, Glabe CG, Yang A, Gallagher M, Ashe $\mathrm{KH}$ (2006) A specific amyloid- $\beta$ protein assembly in the brain impairs memory. Nature 440:352-357. CrossRef Medline

Lesné S, Kotilinek L, Ashe KH (2008) Plaque-bearing mice with reduced levels of oligomeric amyloid- $\beta$ assemblies have intact memory function. Neuroscience 151:745-749. CrossRef Medline

Ma QL, Yang F, Calon F, Ubeda OJ, Hansen JE, Weisbart RH, Beech W, Frautschy SA, Cole GM (2008) p21-activated kinase-aberrant activation and translocation in Alzheimer disease pathogenesis. J Biol Chem 283: 14132-14143. CrossRef Medline

Ma QL, Yang F, Frautschy SA, Cole GM (2012) PAK in Alzheimer disease, Huntington disease and X-linked mental retardation. Cell Logist 2:117125. CrossRef Medline

Martone RL, Zhou H, Atchison K, Comery T, Xu JZ, Huang X, Gong X, Jin M, Kreft A, Harrison B, Mayer SC, Aschmies S, Gonzales C, Zaleska MM, Riddell DR, Wagner E, Lu P, Sun SC, Sonnenberg-Reines J, Oganesian A, et al. (2009) Begacestat (GSI-953): a novel, selective thiophene sulfonamide inhibitor of amyloid precursor protein $\gamma$-secretase for the treatment of Alzheimer's disease. J Pharmacol Exp Ther 331:598-608. CrossRef Medline

Mayford M, Bach ME, Huang YY, Wang L, Hawkins RD, Kandel ER (1996) Control of memory formation through regulated expression of a CaMKII transgene. Science 274:1678-1683. CrossRef Medline

Melnikova T, Fromholt S, Kim H, Lee D, Xu G, Price A, Moore BD, Golde TE, Felsenstein KM, Savonenko A, Borchelt DR (2013) Reversible patho- logic and cognitive phenotypes in an inducible model of Alzheimeramyloidosis. J Neurosci 33:3765-3779. CrossRef Medline

Mendoza-Naranjo A, Contreras-Vallejos E, Henriquez DR, Otth C, Bamburg JR, Maccioni RB, Gonzalez-Billault C (2012) Fibrillar amyloid- $\beta$ 1-42 modifies actin organization affecting the cofilin phosphorylation state: a role for Rac1/cdc42 effector proteins and the slingshot phosphatase. J Alzheimers Dis 29:63-77. CrossRef Medline

Miller TM, Pestronk A, David W, Rothstein J, Simpson E, Appel SH, Andres PL, Mahoney K, Allred P, Alexander K, Ostrow LW, Schoenfeld D, Macklin EA, Norris DA, Manousakis G, Crisp M, Smith R, Bennett CF, Bishop KM, Cudkowicz ME (2013) An antisense oligonucleotide against SOD1 delivered intrathecally for patients with SOD1 familial amyotrophic lateral sclerosis: a phase 1, randomised, first-in-man study. Lancet Neurol 12:435-442. CrossRef Medline

Mitani Y, Yarimizu J, Akashiba H, Shitaka Y, Ni K, Matsuoka N (2013) Amelioration of cognitive deficits in plaque-bearing Alzheimer's disease model mice through selective reduction of nascent soluble $\mathrm{A} \beta 42$ without affecting other $\mathrm{A} \beta$ pools. J Neurochem 125:465-472. CrossRef Medline

Mitani Y, Yarimizu J, Saita K, Uchino H, Akashiba H, Shitaka Y, Ni K, Matsuoka N (2012) Differential effects between $\gamma$-secretase inhibitors and modulators on cognitive function in amyloid precursor proteintransgenic and nontransgenic mice. J Neurosci 32:2037-2050. CrossRef Medline

Mizuno K (2013) Signaling mechanisms and functional roles of cofilin phosphorylation and dephosphorylation. Cell Signal 25:457-469. CrossRef Medline

Morgan D, Diamond DM, Gottschall PE, Ugen KE, Dickey C, Hardy J, Duff K, Jantzen P, DiCarlo G, Wilcock D, Connor K, Hatcher J, Hope C, Gordon M, Arendash GW (2000) A $\beta$ peptide vaccination prevents memory loss in an animal model of Alzheimer's disease. Nature 408:982985. CrossRef Medline

Rodgers SP, Born HA, Das P, Jankowsky JL (2012) Transgenic APP expression during postnatal development causes persistent locomotor hyperactivity in the adult. Mol Neurodegener 7:28. CrossRef Medline

Rogers K, Felsenstein KM, Hrdlicka L, Tu Z, Albayya F, Lee W, Hopp S, Miller MJ, Spaulding D, Yang Z, Hodgdon H, Nolan S, Wen M, Costa D, Blain JF, Freeman E, De Strooper B, Vulsteke V, Scrocchi L, Zetterberg H, et al. (2012) Modulation of $\gamma$-secretase by EVP-0015962 reduces amyloid deposition and behavioral deficits in Tg2576 mice. Mol Neurodegener 7:61. CrossRef Medline

Rozkalne A, Spires-Jones TL, Stern EA, Hyman BT (2009) A single dose of passive immunotherapy has extended benefits on synapses and neurites in an Alzheimer's disease mouse model. Brain Res 1280:178-185. CrossRef Medline

Rust MB, Gurniak CB, Renner M, Vara H, Morando L, Görlich A, SassoèPognetto M, Banchaabouchi MA, Giustetto M, Triller A, Choquet D, Witke W (2010) Learning, AMPA receptor mobility and synaptic plasticity depend on n-cofilin-mediated actin dynamics. EMBO J 29:18891902. CrossRef Medline

Saneyoshi T, Hayashi Y (2012) The $\mathrm{Ca}^{2+}$ and Rho GTPase signaling pathways underlying activity-dependent actin remodeling at dendritic spines. Cytoskeleton 69:545-554. CrossRef Medline

Shankar GM, Bloodgood BL, Townsend M, Walsh DM, Selkoe DJ, Sabatini BL (2007) Natural oligomers of the Alzheimer amyloid- $\beta$ protein induce reversible synapse loss by modulating an NMDA-type glutamate receptor-dependent signaling pathway. J Neurosci 27:2866-2875. CrossRef Medline

Sherman MA, Lesné SE (2011) Detecting A $\beta^{\star} 56$ oligomers in brain tissues. Methods Mol Biol 670:45-56. CrossRef Medline

Spires TL, Meyer-Luehmann M, Stern EA, McLean PJ, Skoch J, Nguyen PT, Bacskai BJ, Hyman BT (2005) Dendritic spine abnormalities in amyloid precursor protein transgenic mice demonstrated by gene transfer and intravital multiphoton microscopy. J Neurosci 25:7278-7287. CrossRef Medline

Spires-Jones T, Knafo S (2012) Spines, plasticity, and cognition in Alzheimer's model mice. Neural Plast 2012:319836. CrossRef Medline

Spires-Jones TL, Meyer-Luehmann M, Osetek JD, Jones PB, Stern EA, Bacskai BJ, Hyman BT (2007) Impaired spine stability underlies plaquerelated spine loss in an Alzheimer's disease mouse model. Am J Pathol 171:1304-1311. CrossRef Medline

Spires-Jones TL, Mielke ML, Rozkalne A, Meyer-Luehmann M, de Calignon A, Bacskai BJ, Schenk D, Hyman BT (2009) Passive immunotherapy 
rapidly increases structural plasticity in a mouse model of Alzheimer disease. Neurobiol Dis 33:213-220. CrossRef Medline

Stern EA, Bacskai BJ, Hickey GA, Attenello FJ, Lombardo JA, Hyman BT (2004) Cortical synaptic integration in vivo is disrupted by amyloid- $\beta$ plaques. J Neurosci 24:4535-4540. CrossRef Medline

Stokin GB, Lillo C, Falzone TL, Brusch RG, Rockenstein E, Mount SL, Raman R, Davies P, Masliah E, Williams DS, Goldstein LS (2005) Axonopathy and transport deficits early in the pathogenesis of Alzheimer's disease. Science 307:1282-1288. CrossRef Medline

Takeda S, Hashimoto T, Roe AD, Hori Y, Spires-Jones TL, Hyman BT (2013) Brain interstitial oligomeric amyloid $\beta$ increases with age and is resistant to clearance from brain in a mouse model of Alzheimer's disease. FASEB J 27:3239-3248. CrossRef Medline

Trinchese F, Liu S, Battaglia F, Walter S, Mathews PM, Arancio O (2004) Progressive age-related development of Alzheimer-like pathology in APP/ PS1 mice. Ann Neurol 55:801-814. CrossRef Medline

Wang A, Das P, Switzer RC 3rd, Golde TE, Jankowsky JL (2011) Robust amyloid clearance in a mouse model of Alzheimer's disease provides novel insights into the mechanism of amyloid- $\beta$ immunotherapy. J Neurosci 31:4124-4136. CrossRef Medline

Wang Y, Dong Q, Xu XF, Feng X, Xin J, Wang DD, Yu H, Tian T, Chen ZY (2013) Phosphorylation of cofilin regulates extinction of conditioned aversive memory via AMPAR trafficking. J Neurosci 33:6423-6433. CrossRef Medline

Wei W, Nguyen LN, Kessels HW, Hagiwara H, Sisodia S, Malinow R (2010) Amyloid $\beta$ from axons and dendrites reduces local spine number and plasticity. Nat Neurosci 13:190-196. CrossRef Medline
Westerman MA, Cooper-Blacketer D, Mariash A, Kotilinek L, Kawarabayashi T, Younkin LH, Carlson GA, Younkin SG, Ashe KH (2002) The relationship between $\mathrm{A} \beta$ and memory in the Tg2576 mouse model of Alzheimer's disease. J Neurosci 22:1858-1867. Medline

Wilcock DM, Rojiani A, Rosenthal A, Subbarao S, Freeman MJ, Gordon MN, Morgan D (2004) Passive immunotherapy against A $\beta$ in aged APPtransgenic mice reverses cognitive deficits and depletes parenchymal amyloid deposits in spite of increased vascular amyloid and microhemorrhage. J Neuroinflammation 1:24. CrossRef Medline

Wilcock DM, Alamed J, Gottschall PE, Grimm J, Rosenthal A, Pons J, Ronan V, Symmonds K, Gordon MN, Morgan D (2006) Deglycosylated antiamyloid- $\beta$ antibodies eliminate cognitive deficits and reduce parenchymal amyloid with minimal vascular consequences in aged amyloid precursor protein transgenic mice. J Neurosci 26:5340-5346. CrossRef Medline

Wilcox KC, Lacor PN, Pitt J, Klein WL (2011) A $\beta$ oligomer-induced synapse degeneration in Alzheimer's disease. Cell Mol Neurobiol 31:939_ 948. CrossRef Medline

Zago W, Buttini M, Comery TA, Nishioka C, Gardai SJ, Seubert P, Games D, Bard F, Schenk D, Kinney GG (2012) Neutralization of soluble, synaptotoxic amyloid $\beta$ species by antibodies is epitope specific. J Neurosci 32:2696-2702. CrossRef Medline

Zhao L, Ma QL, Calon F, Harris-White ME, Yang F, Lim GP, Morihara T, Ubeda OJ, Ambegaokar S, Hansen JE, Weisbart RH, Teter B, Frautschy SA, Cole GM (2006) Role of p21-activated kinase pathway defects in the cognitive deficits of Alzheimer disease. Nat Neurosci 9:234-242. CrossRef Medline 